Preprints of the

Max Planck Institute for

Research on Collective Goods

Bonn 2006/22

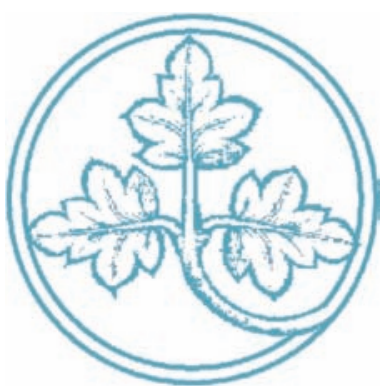

Private Damage Claims and the Passing-On Defense in Horizontal Price-Fixing Cases: An Economist's Perspective

Martin Hellwig

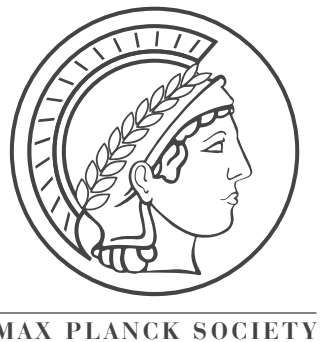




\title{
Private Damage Claims and the Passing-On Defense in Horizontal Price-Fixing Cases: An Economist's Perspective
}

\author{
Martin Hellwig
}

September 2006 


\section{Private Damage Claims and the Passing-On Defense in Horizontal Price-Fixing Cases: An Economist's Perspective ${ }^{1}$}

\section{Introduction and Overview}

The European Court of Justice's Courage decision and the European Commission's Green Paper have put the matter of private claims for damages from antitrust violations on the agenda of European competition policy. The Court stresses the effet utile of allowing private parties to claim damages in antitrust cases. The Commission sees the prospect of private damage awards as an incentive device to strengthen the private enforcement of antitrust law. It hopes that enhanced private enforcement will provide some compensation for the loss of information and control that might be caused by the abandonment of the notification system that was in place before Regulation $1 / 2003$.

This development contrasts with past practice, which has been fairly hostile to private damage claims in antitrust matters. It raises fundamental legal issues, as well as issues of appropriate antitrust policy.

A key issue concerns the relation of the concept of "damages" in antitrust cases to the concept of "damages" in general tort law. This issue is closely linked to the question of the relation between European antitrust law and national tort law. Given the strength that the law derives from the doctrinal unity of civil law, a differentiation between the notions of damages in antitrust cases and in other torts cases seems undesirable. However, tort law, like civil law in general, is a national prerogative. Doctrinal unity in the notion of damages in antitrust cases and in other torts cases in any one jurisdiction may therefore be at odds with the European character of antitrust law and antitrust law enforcement. ${ }^{2}$

Under any law, the assessment of damages raises two fundamental questions:

Who is to have standing to submit claims for damages in antitrust cases?

What is the proper measure of damages?

In antitrust law, these questions are intimately linked. Consider the assessment of damages against producers who have formed an illegal cartel and suppose that the customers of the cartel members are themselves firms that use the good in question as an input into their own production. The cartel's price-fixing has raised costs for the purchasers. However, it is quite likely that they have been able to pass some of the cost increase on to their own customers by raising their

1 Paper presented at the Conference on Private Enforcement in Antitrust, Max Planck Institute for Comparative and International Private Law, Hamburg, April 6 - 7, 2006. For comments on a preliminary version of this paper, I thank Jürgen Basedow, Stefan Bechtold, Felix Bierbrauer, Christoph Engel, and Frank MaierRigaud. I am also grateful for research support from Deutsche Forschungsgemeinschaft through SFB/TR 15. Some of the research for this paper had originally been done in preparation for the German Monopolies Commission's Special Report on the Reform of the Law Against Restraint of Competition, see Monopolkommission, Das allgemeine Wettbewerbsrecht in der Siebten GWB-Novelle - Die Pressefusionskontrolle in der Siebten GWB-Novelle, Sondergutachten 41/42, Nomos Verlag, Baden-Baden 2004.

$2 \quad \ldots$ unless one were to think of a Europeanization of torts in antitrust cases as being the first step towards a Europeanization of civil law altogether! Early on in the discussion about modernization, the German Monopolies Commission pointed to the basic conflict between the national character of tort law and the European character of antitrust as a source of frictions for antitrust enforcement by the national courts. See Monopolkommission, Folgeprobleme der europäischen Kartellrechtsreform, Sondergutachten 32, Nomos Verlag, Baden-Baden 2002, pp. $50 \mathrm{ff}$. 
own prices. The downstream customers are thus indirectly hurt by the cartel's price-fixing. Does this give them standing to claim damages from the cartel members? Moreover, are the direct purchasers' own price increases relevant for the assessment of damages that they can claim against the cartel members?

The Supreme Court of the United States has answered both these questions in the negative. In Hanover Shoe, ${ }^{3}$ it rejected what is known as the passing-on defense, according to which any benefits that the intermediary firm has obtained by raising his own prices must be deducted from the damages that can be claimed against the upstream supplier. In Illinois Brick, it denied standing to indirect purchasers. The Court's judgment in Hanover Shoe was based on the consideration that indirect purchasers tend to be widely dispersed, somewhat removed from the original offense, and therefore too weak to be mounting much of a claim for damages in their own right. Therefore, antitrust offenders might get off too lightly if the passing-on defense was allowed to reduce the direct purchasers' claims. Given this rejection of the passing-on defense, Illinois Brick was based on the consideration that, if the "passing-on theory" was rejected as an argument when given by antitrust offenders, it also had to be rejected as an argument when given by indirect purchasers. ${ }^{5}$

The Supreme Court's rejection of the passing-on defense is based on incentive considerations. The Court considers that, if antitrust offenders get off too lightly, the prospect of liability for private damages may not provide enough of an incentive to refrain from illegal price-fixing. From the perspective of general tort law, at least in Germany, one may ask whether such incentive considerations are compatible with the principle that payments for damages should provide for equitable restitution, i.e. the restoration of positions that the victims would have had in the absence of the offence, and that payments for damages should not provide for the enrichment of victims. Adherents of the passing-on defense argue that this principle is violated if the direct purchaser is allowed to claim the amount by which he was overcharged without any deductions for the extra revenues that he got from his own customers by raising the prices that he was charging them. The passing-on defense is presented as an application of the general principle that damages are to be assessed net of any benefits that the victim of the violation has obtained in the event.

In the following, I will consider the merits of these different positions. Relying on my comparative advantage as an economist, I will focus on what actually happens when the producers of a commodity get together to engage in illegal price-fixing. The results of the analysis are somewhat surprising because they suggest that the positions of both the United States Supreme Court and the proponents of the passing-on defense are flawed. Both have paid too little attention to (i) the fact that damages comprise foregone profits, as well as actual losses, ${ }^{6}$ and (ii) the question of

3 Hanover Shoe Inc. v. United Shoe Machinery Corp. 392 U.S. 481 (1968).

$4 \quad$ Illinois Brick Co. et al. v. Illinois et al. 431 U.S. 720 (1977).

5 This denial of standing to indirect purchasers has met with significant criticism and, indeed, at the State level, a small majority of States have chosen to allow indirect purchaser suits, thus making use of an option that the Supreme Court provided in California v. ARC America Corp. 490 US 93 (1989). For an overview and assessment, see Roger D. Blair and Jeffrey L. Harrison, Reexamining the Role of Illinois Brick in Modern Antitrust Standing Analysis, George Washington Law Review 68 (1999), pp. 1 - 43, Friedrich W. Bulst, Schadensersatzansprüche der Marktgegenseite im Kartellrecht, Europäisches Wirtschaftsrecht 45, Nomos Verlag und Verlag C.H. Beck, Baden-Baden 2006, Marten P. Schinkel, Jan Tuinstra, and Jakob Rüggeberg, Illinois Walls: How Barring Indirect Purchaser Suits Facillitates Collusion, Universiteit van Amsterdam Discussion paper, July 2006.

This is also criticized by Schinkel et al. (supra fn. 5), p. 6, fn. 13. 
what is the proper notion of causation to be used in assessing what damages can be ascribed to the cartel. Once these matters are fully considered, one sees that (i) a rejection of the passing-on defense can be fully compatible with the notion of damages as a device for equitable restitution and (ii) there need not be any firm link between the treatments of passing-on effects for direct purchasers and for indirect purchasers.

Actual losses can be identified with the overcharge on the amount that is actually purchased from the cartel members. In addition to these actual losses, there are foregone profits when the cartel members' overcharging induces the direct buyer to reduce his purchases, thus forego some benefits that he would otherwise have obtained. One reason for this may be that the direct buyer's attempt to pass the cartel price on to his own customers lowers the latter's demand for the direct buyer's product and therefore the direct buyer's need for the input that he buys from the cartel members. A complete account of passing-on effects would have to take account of this business loss, as well as the increased per-unit revenue on the business that is retained. Once this is done, one finds that the business-loss effect may actually outweigh the per-unit revenue enhancing effect, on which the passing-on defense relies. In particular, the paper will show that the businessloss effect always outweighs the per-unit revenue enhancing effect if the direct buyers from the cartel members are not in competition with each other, i.e., if each direct buyer is a monopolist in his own market downstream. In this case, the overcharge on the actual quantity that a direct buyer purchases from the cartel member is a lower bound to the overall damages that he suffers. Any use of the passing-on defense to reduce damage claims below the overcharge on actual purchases would be based on fallacious reasoning. I will show that an appropriate assessment of damages for the direct buyer, taking account of both the business-loss effect and the per-unit revenue enhancing effect actually requires the same procedure as the assessment of damages when the direct buyer is a final consumer; passing-on effects suffered by indirect buyers come on top of the damages suffered by the direct buyer.

Matters are more complicated if the direct buyers from the cartel members are in competition with each other. In this case, the cartel members' price-fixing affects the pattern of competition between the direct buyers. The overcharge raises the input prices of all direct purchasers at the same time and induces all of them to raise their output prices. The business-loss effects from the output-price increase of any one direct buyer are smaller than they would if this direct buyer was the only one to be raising his price. The reason is that the downstream customer who faces a price increase from his supplier may find that the other suppliers have raised their prices as well, and, therefore, there is no point in changing suppliers. Alternatively, one can say that the business-loss effect that a direct buyer experiences when he raises his own price is counteracted by a business-gain effect that is due to the other direct buyers also raising their prices. The increase in the costs that the direct buyer's rivals are bearing benefits the direct buyer and enhances the harm suffered by the direct buyer's customers downstream.

At this point, however, one must be careful about the notion of causation that one is using, i.e., about the standard of comparison used in assessing the damages. Three issues arise. First, the illegal price-fixing of upstream producers involves not one action, but many. There is, first of all, the illegal agreement itself. There is, second, the sale of the good at excessive prices by some cartel member to direct buyer A, in combination with the refusal of all cartel members to sell the good to A at a lower price. There is, third, the sale of the good at excessive prices by some cartel member to direct buyer B, in combination with the refusal of all cartel members to sell the good to $\mathrm{B}$ at a lower price. Which of these actions are deemed to constitute the offense against $\mathrm{A}$ for 
which damages are being assessed? Should we consider all of them together? Or should we consider only those actions that concern A directly, leaving out those actions that concern B?

If $\mathrm{A}$ and $\mathrm{B}$ are competing in a downstream market, the distinction between these two notions of what constitutes the offense against $\mathrm{A}$ is important because anything the cartel members are doing to hurt B is likely to help A. The analysis below will actually show that, if a passing-on defense is to make reduce damages below the overcharge on the amount actually purchased, it must be because the cartel members' actions against B - and B's response to these actions - are treated as part of the offense against $A$ for which damages are being assessed. If the businessloss effect is not matching or outweighing the per-unit revenue effect for $\mathrm{A}$, it is because the cartel members' actions against B relieve the pressures of competition from B to which A is subjected. Under any concept of causation that takes B's price as given and considers only the cartel members' actions against A, the per-unit revenue effect of A increasing his own price would be outweighed by the business-loss effect, and the overcharge on the amount actually purchased would be a lower bound to the true value of damages.

This brings me to a second issue, which concerns the actions of the other direct buyers. If we were to accept the notion that the offense against A for which damages are being assessed comprises the cartel members' actions against B, as well as their actions against A, should B's reaction to the cartel members' overcharging be treated as a part of this package? The benefits that A draws from the cartel members' overcharging B are actually due to this reaction of B. If B did not raise his price in response to the cartel members' overcharging him, the competitive pressure that he exerts on A would actually be unchanged, and the passing-on defense would have to be treated as before, with a business-loss effect outweighing the per-unit revenue effect. For the passing-on defense to be treated differently, one needs to consider both, the cartel members' overcharging B and B's reaction to this overcharging, as being part of the offense against A and providing a countervailing benefit that has to be taken into account in awarding damages. ${ }^{7}$

At this point, the difficulty arises that B is not just reacting to the cartel members' overcharging him. He is also reacting to A's raising his own output price. More precisely, A and B are both raising their output prices because the price-fixing upstream has changed the strategic game between them. How should we deal with the implications of strategic interdependence for the direct purchasers' reactions to the illegal price-fixing upstream? Should we consider the entire movement in the direct purchasers' downstream prices to be induced by the cartel members' actions? If not, where do we draw the line?

If we do consider the entire movement in the direct purchasers' downstream prices to be induced by the cartel members' actions, we may end up reducing the direct purchasers' claims to naught. There are, indeed, cases where the price-fixing upstream relaxes competition among direct purchasers to such an extent that they are better off than they would be without the cartel; the benefits of relaxed competition more than compensate for the increases in input costs.

A third issue concerns the relation between the concept of causation that is used in assessing direct purchasers' claims and the concept of causation that is used in assessing indirect purchasers' claims. If we consider the entire movement in the direct purchasers' downstream prices to be induced by the cartel members' actions, consistency would seem to require that we do so in cases involving indirect purchasers, as well as in cases involving direct purchasers. By this logic, the indirect purchaser would not have to identify which part of the price increase of A, from whom to a business-gain effect that would arise even if A did not change his own price. 
he has bought, was a reaction to the price-fixing upstream having raised his costs and which part was a reaction to B's having been induced to compete less fiercely. Both effects would be ascribed to the cartel.

One may have doubts about the wisdom or the viability of such a regime in which cartel members are held responsible for the entire change in the downstream system that their price-fixing induces. However, if one wants to shield cartel members from indirect-purchaser claims that are based on the entire change in the downstream system that their price-fixing has induced, one must at the same time reject a defense against direct purchasers that is based on this very change in the downstream system. Consistency in the treatment of causation in assessing damages for direct and indirect purchasers then requires that, in assessing damages for a direct buyer $\mathrm{A}$, the actions of A's competitors should be held constant and should not be treated as part of the package of actions whose effects are being considered.

Before I turn to the actual analysis, a disclaimer is in order. This paper does not attempt to provide an encompassing analysis of private damages in antitrust law. It merely tries to present the economist's view of what damages are in price-fixing cases and to relate this view to legal analysis. No account is given of private damages in other antitrust cases. No account is given of the incentives that private parties have to bring such cases or of the relation between private enforcement and private damages to public enforcement and public fines or public leniency programs.

I also leave out the empirical question of what data and what procedures might be used to measure damages in any particular case. This question is important, but, before one addresses it, one needs to know what one is actually looking for, i.e., one needs to resolve the conceptual issue of what acts are to be considered as constituting the offense and what effects are to be taken into account as one assesses damages by comparing actual outcomes with the hypothetical situation that would have arisen if the cartel had not been formed.

\section{The Effects of Price-fixing When Buyers Are Final Consumers}

\subsection{Economic Analysis}

Before considering passing-on effects, I first discuss the assessment of damages from pricefixing in a market where all buyers are final consumers. Suppose that $\mathrm{n}$ suppliers of a good agree to sell the good at the monopoly price $\mathrm{p}^{\mathrm{M}}$. I buy an amount $\mathrm{d}\left(\mathrm{p}^{\mathrm{M}}\right)$ from supplier 1 . What damage do I suffer from the illegal price-fixing?

To answer this question, one must specify a standard of comparison. Such a standard can be based on normative considerations or on a prediction of what would have happened in the hypothetical world in which the offense would not have occurred. One suggestion might be that, without the illegal agreement, each supplier would have been free to offer the good at the price $\mathrm{p}^{\mathrm{M}}$ anyway so that, in fact, I have not suffered any damage at all, at least by comparison to this situation. In opposition to this suggestion, one could argue that such an outcome would be unlikely, because competition would induce suppliers to set prices below $\mathrm{p}^{\mathrm{M}}$, or unacceptable, because monopoly prices violate abuse-of-dominance rules. 
Assuming that all suppliers produce the good at the same constant cost $\mathrm{c}$ per unit, one might predict the competitive outcome to involve every supplier charging a price equal to c. ${ }^{8}$ This prediction would correspond to the Bertrand model of competition among price-setting suppliers. However, if the number of suppliers is small, this prediction is not compatible with the Cournot model of oligopolistic competition in which suppliers choose quantities that they want to supply, leaving the market to find an equilibrating price. ${ }^{9}$ It does, however, correspond to a normative standard that assesses prices in relation to costs or in relation to the prices that would prevail under "perfect competition". In the following, I will assume that the competitive price $\mathrm{p}^{\mathrm{C}}=\mathrm{c}$ is in fact the appropriate standard of comparison.

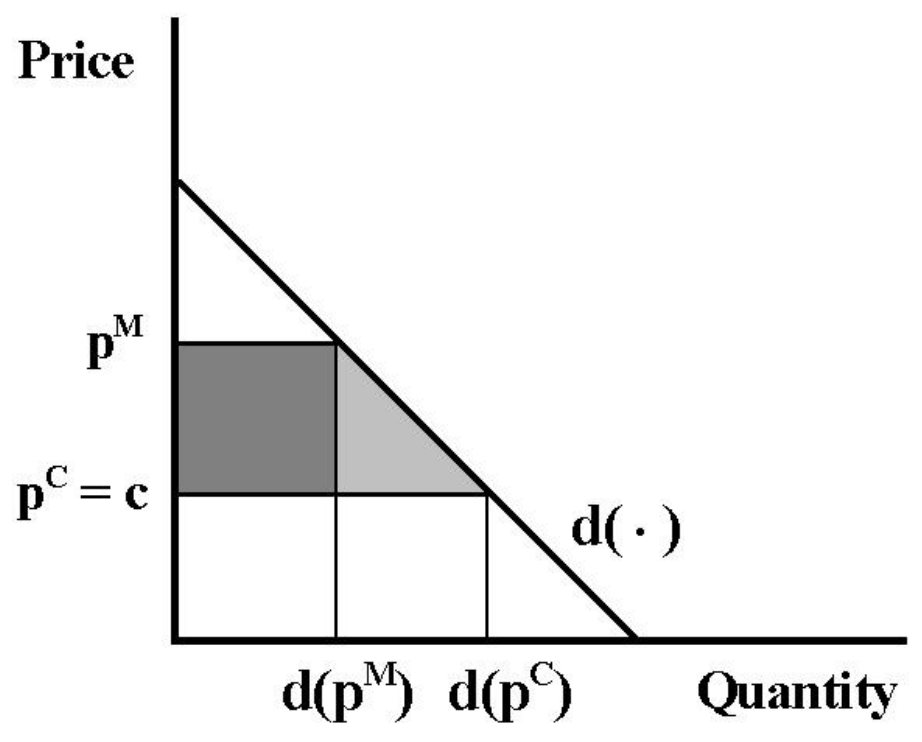

Figure 1: The Effects of Price-fixing on Direct Purchasers Who Are Not Competitors

With this standard of comparison, the effects of the price-fixing are illustrated in Figure 1. In this figure, the downward sloping curve $\mathrm{d}($. ) indicates my demand at different prices. At the cartel price, I buy $d\left(p^{M}\right)$ units of the good; at the competitive price $p^{C}=c$, I buy $d\left(p^{C}\right)$ units. One may presume that $d\left(p^{C}\right)$ is greater than $d\left(p^{M}\right)$, i.e., that the price-fixing reduces my demand for the good. The cartelization thus has two effects:

An allocative effect by which my demand is reduced from $\mathrm{d}\left(\mathrm{p}^{\mathrm{C}}\right)$ to $\mathrm{d}\left(\mathrm{p}^{\mathrm{M}}\right)$ and

A distributive effect by which I am made to pay the amount $\mathrm{p}^{\mathrm{M}} \mathrm{d}\left(\mathrm{p}^{\mathrm{M}}\right)$, rather than $\mathrm{p}^{\mathrm{C}} \mathrm{d}\left(\mathrm{p}^{\mathrm{M}}\right)$ for the $\mathrm{d}\left(\mathrm{p}^{\mathrm{M}}\right)$ units of the good that I actually purchase.

What are the consequences of these effects on the participants' welfare? First, the distributive effect raises the supplier's profits by the amount $\left(p^{M}-p^{C}\right) d\left(p^{M}\right)$, which corresponds to the area of the darkly shaded rectangle with sides $\left(p^{M}-p^{C}\right)$ and $d\left(p^{M}\right)$ in Figure 1 . The distributive effect

8 If different suppliers have different costs, the analysis would be more complicated, but the principles would be similar. In this case, the competitive outcome would be identified with the second-lowest cost level, i.e., the lowest price at which at least two suppliers would be willing to provide the good.

9 For textbook treatments of oligopolistic competition, see Ch. 5 in Jean Tirole, The Theory of Industrial Organization, MIT Press, Cambridge, MA, 1989, or Ch. 12 in Andreu Mas-Colell, Michael D. Whinston, und Jerry R. Green, Microeconomic Theory, Oxford University Press, Oxford 1995. 
lowers my welfare ${ }^{10}$ by the same amount $\left(\mathrm{p}^{\mathrm{M}}-\mathrm{p}^{\mathrm{C}}\right) \mathrm{d}\left(\mathrm{p}^{\mathrm{M}}\right)$. Second, the allocative effect lowers my own welfare without affecting the supplier. This effect corresponds to the area of lightly shaded triangle with base $\left(d\left(p^{C}\right)-d\left(p^{M}\right)\right)$ and height $\left(p^{M}-p^{C}\right)$, i.e. to the product of $\left(d\left(p^{C}\right)-d\left(p^{M}\right)\right)$ and $\left(p^{M}-p^{C}\right) / 2$. The difference $d\left(p^{C}\right)-d\left(p^{M}\right)$ is the foregone quantity; the term $\left(p^{M}-p^{C}\right) / 2$ a measure of the utility loss per unit of foregone quantity. This latter term is equal to the difference between $\left(p^{\mathrm{M}}+p^{\mathrm{C}}\right) / 2$, a measure of the average utility per unit of the foregone quantity, ${ }^{11}$ and the competitive price $\mathrm{p}^{\mathrm{C}}$, which I should pay for each unit in the alternative situation when I buy the amount $\mathrm{d}\left(\mathrm{p}^{\mathrm{C}}\right)$.

From an economic perspective, therefore, the private damages suffered by the buyer as a result of the cartel's raising the price from $\mathrm{p}^{\mathrm{C}}$ to $\mathrm{p}^{\mathrm{M}}$ amount to the sum

$$
\left(\mathrm{p}^{\mathrm{M}}-\mathrm{p}^{\mathrm{C}}\right) \mathrm{d}\left(\mathrm{p}^{\mathrm{M}}\right)+\left(\mathrm{d}\left(\mathrm{p}^{\mathrm{C}}\right)-\mathrm{d}\left(\mathrm{p}^{\mathrm{M}}\right)\right)\left(\mathrm{p}^{\mathrm{M}}-\mathrm{p}^{\mathrm{C}}\right) / 2
$$

of the damages that he suffers from the distributive and allocative effects taken together. I will refer to this quantity as the economic private damages of the buyer. In Figure 1, it corresponds to the sum of the darkly shaded rectangle and the lightly shaded triangle, i.e. to the shaded trapezoid between the two horizontal lines at prices $\mathrm{p}^{\mathrm{C}}$ and $\mathrm{p}^{\mathrm{M}}$, the vertical axis, and the demand curve.

The sum of private damages that the buyer suffers from the distributive and allocative effects of the price-fixing can be interpreted as an externality that the cartel imposes on the buyer. As such, it provides a proper starting point for setting incentives. One may worry about the effects of the uncertainty of cartel detection. If cartel detection were assured, a rule awarding economic private damages to the buyer would effectively discourage cartel formation. If cartel detection is uncertain, additional incentive devices may be needed in order to counterbalance the positive incentives for cartel formation that are provided by the prospect of gains when the cartel is not detected. Even in this case though, the externality that the cartel imposes on the buyer when it remains undetected provides a suitable starting point for setting proper incentives. However, I will not go into this issue any further; instead, I will focus on the use of total private damages as a measure of the externality that the cartel imposes on the buyer.

\subsection{Economic Private Damages and the Assessment of Legal Liability}

How do these economic considerations fit into the legal framework that is provided by general tort law? Is an award of economic private damages to the buyer compatible with the principle that private damages should provide for equitable restitution and not serve as a source of enrichment for the plaintiff?

The answer to this question depends on the hypothetical alternative situation that is used as a reference point for assessing equitable restitution. If the alternative situation is construed as being one where the buyer is given the option to negotiate with any of the suppliers in the absence of a cartel agreement among suppliers and if one takes the decision autonomy of the suppliers in such negotiations for granted, one cannot reject the possibility that each supplier would insist on

10 More precisely, the money equivalent of the welfare level that I attain.

11 At $\mathrm{d}\left(\mathrm{p}^{\mathrm{M}}\right)$, the last unit purchased is worth $\mathrm{p}^{\mathrm{M}}$ to the buyer, the first additional unit is worth roughly the same; as additional units are being purchased, their value decreases until it reaches approximately $\mathrm{p}^{\mathrm{C}}$ at the quantity $d\left(p^{C}\right)$. The average $\left(p^{M}+p^{C}\right) / 2$ is precise if the demand function is linear. Otherwise, it is an approximation; a precise measure would be given by the integral under the demand curve between $\mathrm{d}\left(\mathrm{p}^{\mathrm{M}}\right)$ and $\mathrm{d}\left(\mathrm{p}^{\mathrm{C}}\right)$. 
the monopoly price $\mathrm{p}^{\mathrm{M}}$. In this case, there is no role at all for damages as a device for equitable restitution.

If, instead, the alternative situation is construed as being one where the buyer is given the option to buy any quantity he wants at the competitive price $\mathrm{p}^{\mathrm{C}}$, the effect of the cartel is to replace this option with the option to buy any quantity he wants at the monopoly price $\mathrm{p}^{\mathrm{M}}$. In this case, to award economic private damages to the buyer is fully in accord with the notion of equitable restitution. The distributive effect corresponds to actual damages from overcharging on the amount $\mathrm{d}\left(\mathrm{p}^{\mathrm{M}}\right)$; the allocative effect corresponds to profits that are foregone because the loss of the option to buy at the price $\mathrm{p}^{\mathrm{C}}$ induces the buyer to reduce the quantity that he wants to buy.

Tort law as such provides little guidance as to how the hypothetical alternative situation is to be construed. In principle, either of the above constructions might be seen as fitting into the framework of general tort law. However, the legal norm whose violation provides the plaintiff with a claim for damages provides some guidance on how the hypothetical alternative situation is to be construed.

The first of the two constructions above is hardly compatible with the intentions of antitrust legislation and jurisdiction when they provide for awarding damages to victims of antitrust violations. If damage claims were deemed to be moot because, even in the absence of a cartel agreement, the supplier would have been free to insist on the cartel price $\mathrm{p}^{\mathrm{M}}$, this would negate the very notion that cartelization is an offense not only against the law, but also against the customers, who should therefore be put into a position to obtain restitution through the payment of damages.

By contrast, the second construction is compatible with the intentions of antitrust legislation and jurisdiction. The notion that cartelization is an offense against customers for which they should be able to claim damages is based on the view that, in the absence of a cartel agreement, the customers would have been able to purchase the good at a lower price. The notion that, without the cartel agreement, the buyer would have or should have the option to buy any quantity that he wants at the competitive price $\mathrm{p}^{\mathrm{C}}=\mathrm{c}$ is in tune with this very assessment.

Given the diversity of models and experiences of oligopolistic markets, one may question whether the competitive price $\mathrm{p}^{\mathrm{C}}=\mathrm{c}$ would actually have prevailed in the absence of the cartel agreement. In most oligopolistic markets, this seems quite unlikely. However, the price $\mathrm{p}^{\mathrm{C}}=\mathrm{c}$ does correspond to the competitive-pricing norm that appears elsewhere in antitrust law. Moreover, by comparison to any alternative, it has the advantage of being relatively simple. The attempt to ascertain the cost $\mathrm{c}$ in an actual court proceeding is difficult enough; but it is immeasurably easier than the attempt to ascertain the precise nature of the strategic interdependence between, say, two large and three small suppliers.

Treating the alternative situation as one where the buyer has an option to buy any quantity that he wants at the competitive price $\mathrm{p}^{\mathrm{C}}$ and therefore awarding economic private damages to the buyer, would be analogous to the treatment of damages for breach of contract when the buyer has a contract providing for the purchase of the quantity $d\left(p^{C}\right)$ at the price $p^{C}$. If the seller breaches this contract and replaces it by the option to buy any quantity that the buyer wants at the monopoly price $\mathrm{p}^{\mathrm{M}}$, the buyer is also compensated for foregone profits, as well as actual losses. From the perspective of legal doctrine, there may be a difference between damages in contracts and damages in torts. Whereas in contract law, we focus on the buyer's interest in seeing a contract fulfilled, in antitrust law, we focus on the potential buyer's interest in having suppliers desist from price-fixing. However, if the legal norm that provides the basis for damage 
claims against price-fixing is construed with reference to a competitive-pricing norm, the potential buyer's chance to buy any quantity that he wants at the competitive price $\mathrm{p}^{\mathrm{C}}=\mathrm{c}$ should, at least in principle, be deemed to be within the sphere of protection provided by the law.

However, awarding economic private damages requires a departure from current practice, not only in those countries that haven't allowed for private damages from antitrust violations at all, but also in the United States. Jurisdiction in the United States has awarded damages from what I have called "the distributive effect" of the cartel, i.e., the actual amount overcharged, but not from the allocative effect. ${ }^{12}$ I consider this to be problematic.

There are good reasons for being cautious about the allocative effect in practice. After all, it raises a serious information problem: In addition to the actual price $\mathrm{p}^{\mathrm{M}}$ and quantity $\mathrm{d}\left(\mathrm{p}^{\mathrm{M}}\right)$, which may be deemed to be verifiable, in any given case, one needs to ascertain not only the competitive price $\mathrm{p}^{\mathrm{C}}$, but also the quantity $d\left(\mathrm{p}^{\mathrm{C}}\right)$ that the buyer would have purchased at the price $\mathrm{p}^{\mathrm{C}}$. Ascertaining $p^{C}$ with any degree of reliability is difficult enough and may cause problems even for assessing the distributive effect of the cartelization. Ascertaining $d\left(p^{C}\right)$ may be close to impossible because this information is privy to the buyer, and he has no incentive to be honest in reporting it. ${ }^{13}$ We may therefore want to be cautious about accepting claims on the basis of foregone profits from additional units that would have been purchased if the price had been $\mathrm{p}^{\mathrm{C}}$ rather than $\mathrm{p}^{\mathrm{M}}$. Indeed, the plaintiffs themselves may want to refrain from such claims because they fear their repercussions for court proceedings. Such repercussions may range from unconscionable delays due to the greater complexity of the claims to an increased risk of losing in court altogether.

However, these difficulties of dealing with the allocative effect in practice should not lead us to neglect it in principle. At the conceptual level, there is no problem in allowing for the allocative effect, in particular, no issue of incompatibility with general tort law. Moreover, as will be seen in the following section, neglect of the allocative effect at the conceptual level is a source of serious flaws in thinking about passing-on effects.

\section{The Effects of Price-fixing When Buyers Are Downstream Monopolists}

\subsection{Economic Analysis}

In this and the following section, I consider the case where the cartel members are selling to other firms that use the good in question as an input into their own production and sell their own outputs to final consumers downstream. To distinguish these firms from the input producers upstream, I refer to them as "intermediaries", without thereby implying that they are intermediaries in the usual sense of merchants, banks, etc. In this section, I treat the case where each intermediary is a monopolist in his own downstream market. In the following section, I will study the case where intermediaries are in monopolistic competition with each other.

12 This was established in American Crystal Sugar Co. v. Mandeville Island Farms, 195 F:2d_622 (9th Cir., 1952). For a critique, see Schinkel et al. (supra fn. 6).

13 One might, however think about estimating it. For example, aggregate market data might permit an econometric estimation of the aggregate demand function $\mathrm{D}($.) of all buyers. This estimation would provide a prediction of the aggregate demand $\mathrm{D}\left(\mathrm{p}^{\mathrm{C}}\right)$ at the competitive price $\mathrm{p}^{\mathrm{C}}$. Under the assumption that, when the price drops from $\mathrm{p}^{\mathrm{M}}$ to $\mathrm{p}^{\mathrm{C}}$, individual demands increase in proportion to the increase in aggregate demand, one predicts $d\left(p^{C}\right)$ to be equal to $d\left(p^{M}\right) D\left(p^{C}\right) / D\left(p^{M}\right)$. 
If intermediaries are monopolists in the downstream markets, there is no role for strategic interaction among intermediaries. I can therefore focus on the effects of price-fixing upstream on one intermediary in isolation, just as, in the preceding section, I focussed on the effects of pricefixing on one consumer. Let $q$ denote the output price of this intermediary. At a given output price $q$, the intermediary faces an aggregate demand $E(q)$. If he satisfies this demand, he obtains the revenue $\mathrm{R}(\mathrm{q})=\mathrm{q} \mathrm{E}(\mathrm{q})$. He also incurs a cost because he has to buy the inputs he uses to produce the quantity $\mathrm{E}(\mathrm{q})$. I distinguish between the input he buys from the cartel members and an aggregate of all other inputs. For simplicity, I set the price of the latter equal to one. If he buys $d$ units of the former and $\mathrm{y}$ units of the latter, his cost is $\mathrm{K}=\mathrm{pd}+\mathrm{y}$. His overall profit is

$$
\mathrm{R}(\mathrm{q})-\mathrm{pd}-\mathrm{y} \text {. }
$$

For a given input price $\mathrm{p}$, he chooses his own output price $\mathrm{q}$, as well as his input purchases $\mathrm{d}$ and $\mathrm{y}$ so as to maximize this profit under the constraint that the input combination $(\mathrm{d}, \mathrm{y})$ is sufficient to produce the output $\mathrm{E}(\mathrm{q})$ that he needs to satisfy his customers' demand at the price q. I denote the resulting choices as $q(p), d(p), y(p)$. These choices provide him with the maximal profit

$$
\mathrm{V}(\mathrm{p})=\mathrm{R}(\mathrm{q}(\mathrm{p}))-\mathrm{pd}(\mathrm{p})-\mathrm{y}(\mathrm{p})
$$

What are the effects of price-fixing upstream? To study this question, I again assume that the cartel members charge the monopoly price $\mathrm{p}^{\mathrm{M}}$, and that, without the cartelization, the price would be equal to the competitive price $p^{C}$. The intermediary reacts to the price-fixing by raising his output price from $\mathrm{q}\left(\mathrm{p}^{\mathrm{C}}\right)$ to $\mathrm{q}\left(\mathrm{p}^{\mathrm{M}}\right)$ and by adjusting his input demands from $\mathrm{d}\left(\mathrm{p}^{\mathrm{C}}\right), \mathrm{y}\left(\mathrm{p}^{\mathrm{C}}\right)$ to $\mathrm{d}\left(\mathrm{p}^{\mathrm{M}}\right), \mathrm{y}\left(\mathrm{p}^{\mathrm{M}}\right)$. His profit changes from $\mathrm{V}\left(\mathrm{p}^{\mathrm{C}}\right)$ to $\mathrm{V}\left(\mathrm{p}^{\mathrm{M}}\right)$. I claim that his profit decreases and that the amount of the decrease is no less than the overcharge $\left(p^{M}-p^{C}\right) d\left(p^{M}\right)$ on the amount that he actually purchases from the cartel members.

The argument that supports this claim is illustrated in Figures 2 and 3. Figure 2 shows the implications of different output prices chosen by the intermediary when the input price is $\mathrm{p}^{\mathrm{C}}$. Figure 3 shows the effects of the input-price increase from $p^{C}$ to $p^{M}$ on the intermediary's profits. The curve $\mathrm{E}($.$) in these figures represents the downstream customers' demand function. For any$ price $\mathrm{q}$ that the intermediary sets, $\mathrm{E}(\mathrm{q})$ is the demand that he encounters. For $\mathrm{q}$, the revenue $\mathrm{R}(\mathrm{q})$ is equal to the area of the rectangle "under the demand curve", i.e. the rectangle to the southwest of the demand point (E(q), q) in the figure, which has sides of lengths $E(q)$ and $q$.

On the cost side, Figures 2 and 3 are drawn under the assumption that the intermediary uses only one input, the one he buys from the cartel members, and that he needs $\delta$ units of the input to produce one unit of his output. As will be seen below, the analysis does not hinge on this assumption. Given this assumption, the cost of producing any amount $\mathrm{E}$ is $\delta \mathrm{p}$ times $\mathrm{E}$. Thus, the intermediary's cost is $\delta \mathrm{p} \mathrm{E}(\mathrm{q})$ if he chooses the output price $\mathrm{q}$ and serves the demand $\mathrm{E}(\mathrm{q})$. He works with a constant unit $\operatorname{cost} \mathrm{k}(\mathrm{p})=\delta \mathrm{p}$. For $\mathrm{p}=\mathrm{p}^{\mathrm{C}}$, this constant unit cost is represented by the horizontal line with intercept $\mathrm{k}\left(\mathrm{p}^{\mathrm{C}}\right)=\delta \mathrm{p}^{\mathrm{C}}$. For any output price $\mathrm{q}$ that the intermediary might choose, the cost of serving the demand $\mathrm{E}(\mathrm{q})$ corresponds to the rectangle between this horizontal line, the axes, and a vertical line at the level of the demand $E(q)$. 


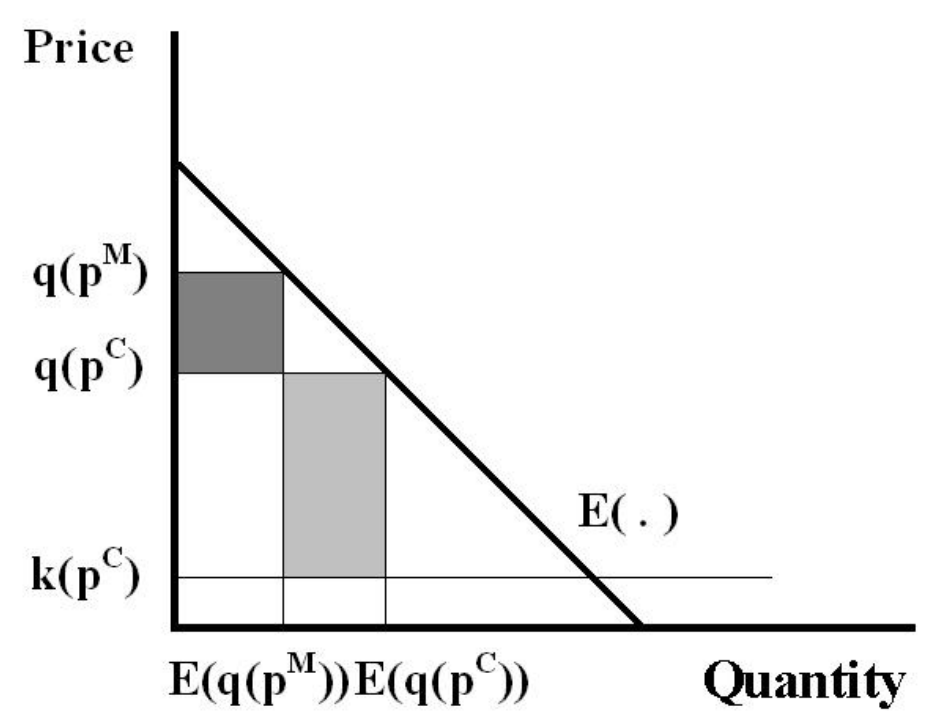

Figure 2: The intermediary's choice when the input price is $p^{c}$

Now consider the intermediary's choice of output price when the input price is $\mathrm{p}^{\mathrm{C}}$. For any $q$ that he might choose, his profit is $\left(\mathrm{q}-\mathrm{k}\left(\mathrm{p}^{\mathrm{C}}\right)\right) \mathrm{E}(\mathrm{q})$. He chooses the price $\mathrm{q}\left(\mathrm{p}^{\mathrm{C}}\right)$ to maximize his profit. Figure 2 illustrates the tradeoff that underlies this choice. The maximal profit, $\left(\mathrm{q}^{\mathrm{C}}\left(\mathrm{p}^{\mathrm{C}}\right)-\mathrm{k}\left(\mathrm{p}^{\mathrm{C}}\right)\right)$ $E\left(q\left(p^{C}\right)\right)$, corresponds to the area of the rectangle with side lengths $\left(q\left(p^{C}\right)-k\left(p^{C}\right)\right)$ and $E\left(q\left(p^{C}\right)\right)$. If he were to choose any higher price, e.g., the price $q\left(p^{M}\right)$ in Figure 2, he would earn more per unit that he sells, but he would also sell fewer units. He is thus trading off the effects of an increase in per-unit revenue against a business-loss effect. The implications of these effects for his profits are represented by the shaded areas in the figure:

The business-loss effect reduces his profit by the product $q\left(p^{C}\right)-k\left(p^{C}\right)$ times $E\left(q\left(p^{C}\right)\right)-E\left(q\left(p^{M}\right)\right)$, of his margin times the quantity reduction; this product is equal to the area of the lightly shaded rectangle in the figure.

The per-unit revenue effect raises his profits by the product $q\left(p^{M}\right)-q\left(p^{C}\right)$ times $E\left(q\left(p^{M}\right)\right)$, the price increase times with the quantity that he actually sells at the higher price; this product is equal to the area of the darkly shaded rectangle in the figure.

The very definition of $\mathrm{q}\left(\mathrm{p}^{\mathrm{C}}\right)$ as a price that maximizes the intermediary's profits when the input price is $\mathrm{p}^{\mathrm{C}}$ implies that, if he were to move to any higher price, the business-loss effect would outweigh the effect of higher per-unit revenues, so that his overall profit must decrease. ${ }^{14}$ Thus, with $\mathrm{q}\left(\mathrm{p}^{\mathrm{M}}\right)>\mathrm{q}\left(\mathrm{p}^{\mathrm{C}}\right)$, the lightly shaded area in Figure 2 is necessarily larger than the darkly shaded area.

14 If he were to move to a price below $\mathrm{p}^{\mathrm{C}}$, the effect of lower per-unit revenues must outweigh the business gain effect of the move, so that his overall profit would also decrease. 


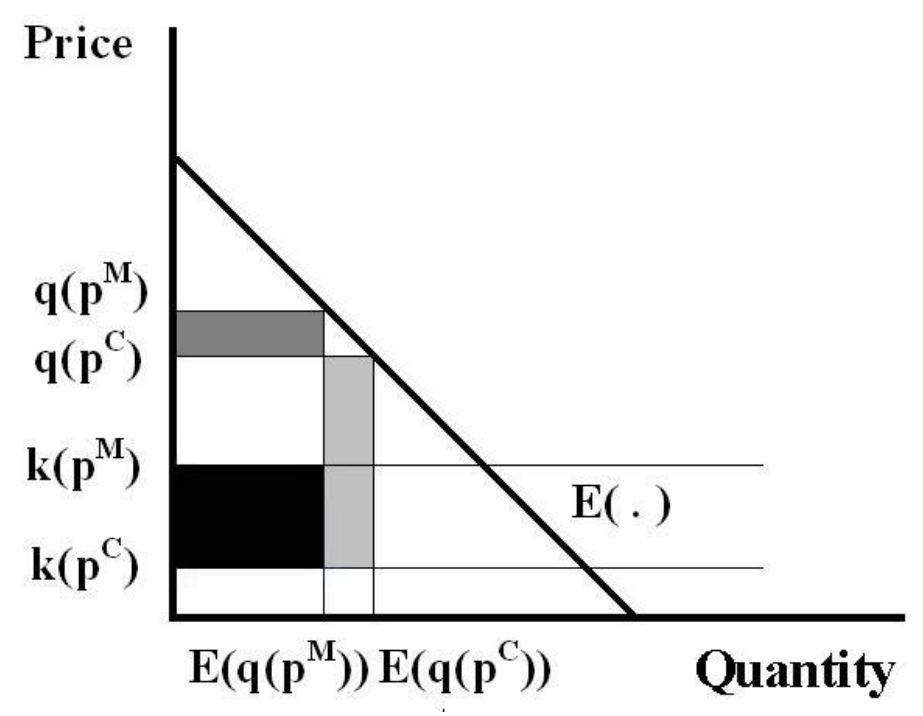

Figure 3: The effects of an input price increase on the intermediary's profits

On the basis of these preliminaries, Figure 3 exhibits the effects of an input price increase from $\mathrm{p}^{\mathrm{C}}$ to $\mathrm{p}^{\mathrm{M}}$. The figure is the same as Figure 2, except that it also contains a horizontal line with intercept $\mathrm{k}\left(\mathrm{p}^{\mathrm{M}}\right)=\delta \mathrm{p}^{\mathrm{M}}$ corresponding to the intermediary's unit cost when the input price is $\mathrm{p}^{\mathrm{M}}$. The input price increase from $\mathrm{p}^{\mathrm{C}}$ to $\mathrm{p}^{\mathrm{M}}$ and the induced increase in the intermediary's own output price from $q\left(p^{C}\right)$ to $q\left(p^{M}\right)$ have three effects on the intermediary's profits: a per-unit revenue effect, a business-loss effect, and a cost effect. The per-unit revenue effect and the business-loss effect are the same as in Figure 2. They are again represented by the darkly and lightly shaded rectangles. The cost effect is given by the product of the increase $k\left(p^{M}\right)-k\left(p^{C}\right)$ in unit costs times the quantity $\mathrm{E}\left(\mathrm{q}\left(\mathrm{p}^{\mathrm{M}}\right)\right)$ that the intermediary actually sells at the higher price $\mathrm{q}\left(\mathrm{p}^{\mathrm{M}}\right)$; this product corresponds to the area of the rectangle that is drawn in black in the figure.

Now we can pull the argument together: The total effect of the input price increase from $\mathrm{p}^{\mathrm{C}}$ to $\mathrm{p}^{\mathrm{M}}$ on the intermediary's profits is given by the cost effect plus the business-loss effect minus the per-unit revenue effect, i.e. the sum of the areas of the black and light grey rectangles minus the area of the dark grey rectangle. From the previous discussion of Figure 2 and the comparison of the intermediary's profits at $\mathrm{q}\left(\mathrm{p}^{\mathrm{C}}\right)$ and $\mathrm{q}\left(\mathrm{p}^{\mathrm{M}}\right)$ when the input price is $\mathrm{p}^{\mathrm{C}}$, we know that the lightly shaded area in Figure 3 is larger than the darkly shaded area, i.e. that the business-loss effect of the output price increase from $q\left(p^{C}\right)$ to $q\left(p^{M}\right)$ outweighs the per-unit revenue effect. Therefore the total effect of the input price increase from $\mathrm{p}^{\mathrm{C}}$ to $\mathrm{p}^{\mathrm{M}}$ on the intermediary's profits is a decrease, which is at least as large as the cost effect, the area of the black rectangle in the figure. Because $\mathrm{k}(\mathrm{p})=\delta \mathrm{p}$ for any $\mathrm{p}$, this cost effect is actually equal to $\left(\mathrm{p}^{\mathrm{M}}-\mathrm{p}^{\mathrm{C}}\right)$ times $\delta \mathrm{E}\left(\mathrm{q}\left(\mathrm{p}^{\mathrm{M}}\right)\right)$, which is just the overcharge on the amount $\mathrm{d}\left(\mathrm{p}^{\mathrm{M}}\right)=\delta \mathrm{E}\left(\mathrm{q}\left(\mathrm{p}^{\mathrm{M}}\right)\right)$ of the input that the intermediary must purchase from the cartel members to satisfy the demand $\mathrm{E}\left(\mathrm{q}\left(\mathrm{p}^{\mathrm{M}}\right)\right)$.

To see that this conclusion holds quite generally, go back to the equation $\mathrm{V}(\mathrm{p})=\mathrm{R}(\mathrm{q}(\mathrm{p}))-\mathrm{pd}(\mathrm{p})$ $-y(p)$ for the maximum profits of the intermediary as a function of the input price $p$. Observe that, when the input price is $p^{\mathrm{C}}$, the intermediary would be free to choose the output price $q\left(p^{\mathrm{M}}\right)$ and to use the input combination $\mathrm{d}\left(\mathrm{p}^{\mathrm{M}}\right), \mathrm{y}\left(\mathrm{p}^{\mathrm{M}}\right)$ to serve the demand $\mathrm{E}\left(\mathrm{q}\left(\mathrm{p}^{\mathrm{M}}\right)\right)$. The fact that he 
does not do so implies that, at the input price $\mathrm{p}^{\mathrm{C}}$, this choice is less profitable than the choice of $q\left(p^{C}\right)$ and $d\left(p^{C}\right), y\left(p^{C}\right)$. Thus, it must be the case that $V\left(p^{C}\right)$ is greater than or equal to

$$
R\left(q\left(p^{M}\right)\right)-p^{C} d\left(p^{M}\right)-y\left(p^{M}\right)=R\left(q\left(p^{M}\right)\right)-p^{M} d\left(p^{M}\right)-y\left(p^{M}\right)+\left(p^{M}-p^{C}\right) d\left(p^{M}\right) .
$$

Because, by definition, $V\left(p^{M}\right)=R\left(q\left(p^{M}\right)\right)-p^{M} d\left(p^{M}\right)-y\left(p^{M}\right)$, it follows that

$$
V\left(p^{C}\right) \text { is greater than or equal to } V\left(p^{M}\right)+\left(p^{M}-p^{C}\right) d\left(p^{M}\right) \text {, }
$$

which is precisely the claim that the overcharge on the actual purchase $d\left(p^{\mathrm{M}}\right)$ is a lower bound for the detrimental effects of the input price increase on the intermediary's profits. In this assessment, all adjustments in the intermediary's output price and input demands are taken into account. There is no room for a passing-on defense to reduce the damage assessment below the actual overcharge. Proponents of the passing-on defense who try to do so anyway are simply forgetting about the business-loss effect that results from the intermediary's price increase.

What can be said about the actual size of the damage that is suffered by the intermediary? In the Appendix to this paper, I show that the answer to this question is again provided by Figure 1, where $\mathrm{d}($. ) now is the intermediary's demand function for the cartel good. The welfare loss that the intermediary suffers from the illegal price-fixing in the input market, i.e., the difference $\mathrm{V}\left(\mathrm{p}^{\mathrm{C}}\right)-\mathrm{V}\left(\mathrm{p}^{\mathrm{M}}\right)$, is equal to the area of the shaded trapezoid between the two horizontal lines at prices $\mathrm{p}^{\mathrm{C}}$ and $\mathrm{p}^{\mathrm{M}}$, the vertical axis and the demand curve; if the demand curve takes the linear form shown in Figure 1, this area is again equal to the sum

$$
\left(\mathrm{p}^{\mathrm{M}}-\mathrm{p}^{\mathrm{C}}\right) \mathrm{d}\left(\mathrm{p}^{\mathrm{M}}\right)+\left(\mathrm{d}\left(\mathrm{p}^{\mathrm{C}}\right)-\mathrm{d}\left(\mathrm{p}^{\mathrm{M}}\right)\right)\left(\mathrm{p}^{\mathrm{M}}-\mathrm{p}^{\mathrm{C}}\right) / 2
$$

of the distributive effect from the overcharge $\left(\mathrm{p}^{\mathrm{M}}-\mathrm{p}^{\mathrm{C}}\right) \mathrm{d}\left(\mathrm{p}^{\mathrm{M}}\right)$ and the allocative effect associated with the intermediary's reducing his demand for the cartel good.

The demand reduction here is due to (i) the intermediary's substituting away from the cartel good and (ii) the intermediary's producing less because his own price increase induces a business-loss effect. Both adjustments make the intermediary better off than he would be otherwise and reduce his damages below the amount $\left(p^{\mathrm{M}}-\mathrm{p}^{\mathrm{C}}\right) \mathrm{d}\left(\mathrm{p}^{\mathrm{C}}\right)$ which would be the overcharge if he continued to buy the quantity $\mathrm{d}\left(\mathrm{p}^{\mathrm{C}}\right)$. This observation highlights the grain of truth in the passingon defense: An assessment of damages according to the overcharge $\left(p^{M}-p^{C}\right) d\left(p^{C}\right)$ on the quantity that the intermediary would buy at the competitive price $\mathrm{p}^{\mathrm{C}}$ would be exaggerated.

However, the adjustments do involve a loss of profit opportunities. In particular, the businessloss effect dominates the per-unit revenue effect of the intermediary's own price increase.

Therefore, the shaded trapezoid in Figure 1 is still larger than the rectangle with base $d\left(p^{M}\right)$ and height $\left(p^{M}-p^{C}\right)$. Considering only the distributive effect $\left(p^{M}-p^{C}\right) d\left(p^{M}\right)$ and then applying the passing-on defense would amount to a fallacious double counting of passing-on effects, as well as a neglect of the allocative effect of the price-fixing.

\subsection{Implications for the Assessment of Legal Liabilities Towards Direct Buyers}

The economic analysis thus shows that there is no difference between the assessment of economic private damages from price-fixing for a consumer and for an intermediary who is a downstream monopolist. If all effects are properly taken into account, the per-unit revenue effect of the intermediary's own price increase, on which the passing-on defense builds, is dominated by the business-loss effect. If the business-loss effect for the intermediary is neglected, the passing- 
on defense results in an inappropriate understatement of the economic private damages that the intermediary suffers from the price-fixing upstream.

Given that there is no difference in principle between the assessment of economic private damages from price-fixing for a consumer and for an intermediary who is a downstream monopolist, there is no need to say anything more about the relation between the results of the economic analysis and the law. Everything that was said about this in Section 2 can be directly applied here. In particular, an assessment of economic private damages is legally mandated if the hypothetical alternative situation that provides the standard for assessing equitable restitution is identified with the intermediary's having an option to buy any quantity of the input that he wants at the competitive price $\mathrm{p}^{\mathrm{C}}$. In this assessment, the passing-on defense is already taken into account.

As discussed in Section 2, there may be practical procedural reasons for neglecting allocative effects and limiting damages to the distributive effect, i.e., the overcharge $\left(p^{M}-p^{C}\right) d\left(p^{M}\right)$ on the quantity that the intermediary actually buys at the price $\mathrm{p}^{\mathrm{M}}$. However, when this is done, it is no longer possible to employ a passing-on defense to reduce damages below the distributive effect. Any attempt to do so would be downright fallacious because, when all effects of the intermediary's own price increase are taken into account, the damage that is suffered by the intermediary is never smaller than the damage from the distributive effect. Denying the passing-on defense while limiting damages to the overcharge is fully compatible with the principle that damage awards should not be a source of enrichment. ${ }^{15}$ Any suggestion to the contrary must neglect the business-loss effect and is therefore flawed.

\subsection{Implications for the Assessment of Legal Liabilities Towards Indirect Purchasers}

What about indirect purchasers, i.e., what about the intermediary's own clients? So far, they have played no role at all, except to the extent that their aggregate demand function $\mathrm{E}($. ) affects the intermediary's profit maximization. If the price-fixing upstream induces the intermediary to raise his price from $\mathrm{q}\left(\mathrm{p}^{\mathrm{C}}\right)$ to $\mathrm{q}\left(\mathrm{p}^{\mathrm{M}}\right)$, the indirect purchasers suffer a welfare loss. Analysis of this welfare loss proceeds along the same lines as in the preceding section, i.e., there are an allocative effect and a distributive effect. For an individual consumer with demand function e( . ), these effects are illustrated in Figure 4, which is the same as Figure 1, except that we are now dealing with the intermediary's output rather than the cartel members' output.

15 One might have qualms about the intermediary's own exploitation of monopoly power in the downstream market. However, that is quite another matter, which needs to be treated on its own merits. In some cases, e.g. when the intermediary's monopoly position is the result of a patent, his exploitation of this position would be unproblematic anyway. 


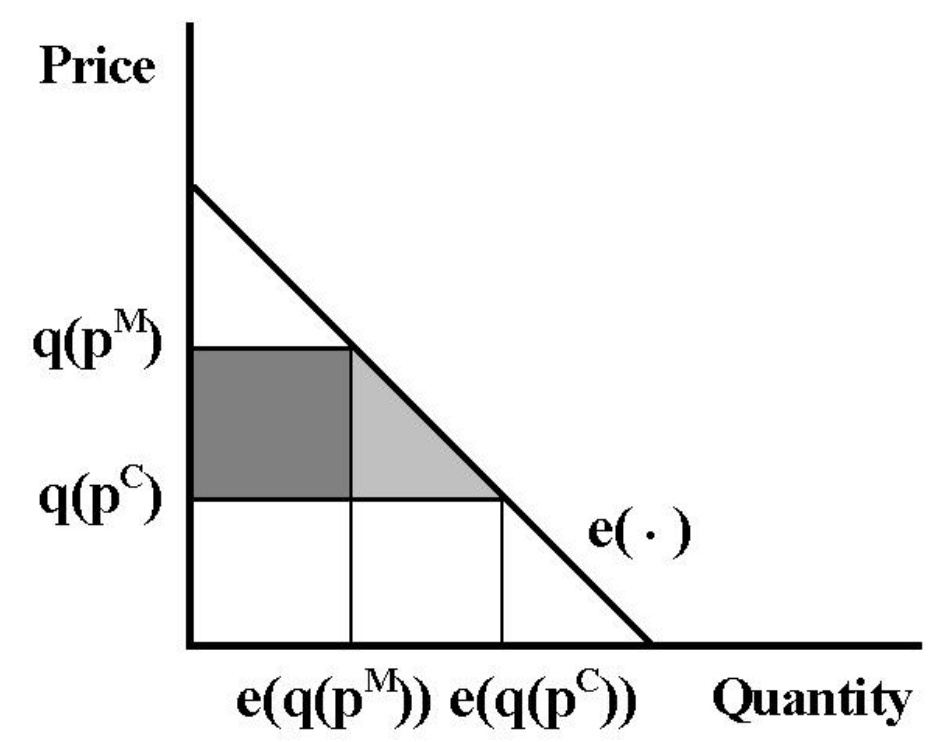

Figure 4: The Effects of Upstream Price-fixing on Indirect Buyers When Direct Buyers Are Not in Competition With Each Other

By the same reasoning as in Section 2, this consumer suffers economic private damages

$$
\left(q\left(p^{M}\right)-q\left(p^{C}\right)\right) e\left(q\left(p^{M}\right)\right)+\left(e\left(q\left(p^{C}\right)\right)-e\left(q\left(p^{M}\right)\right)\left(\left(q\left(p^{M}\right)-q\left(p^{C}\right)\right) / 2\right.\right.
$$

when the price-fixing upstream induces the intermediary to raise his price from $q\left(p^{C}\right)$ to $q\left(p^{M}\right)$. In Figure 3, this corresponds to the shaded trapezoid between the two horizontal lines at prices $\mathrm{q}\left(\mathrm{p}^{\mathrm{C}}\right)$ and $\mathrm{q}\left(\mathrm{p}^{\mathrm{M}}\right)$, the vertical axis, and the demand curve $\mathrm{e}($. $)$. The first term corresponds to the distributive effect, again shown by a darkly shaded rectangle, the second term to the allocative effect, again shown by a lightly shaded triangle.

The economic private damages suffered by the downstream consumer have little to do with the assessment of damages suffered by the intermediaries. To be sure, the distributive effect $\left(\mathrm{q}\left(\mathrm{p}^{\mathrm{M}}\right)\right.$ $\left.q\left(p^{C}\right)\right) e\left(q\left(p^{M}\right)\right)$ corresponds to the revenue enhancement per unit sold that an intermediary obtains when he raises his price. However, as explained above, the revenue enhancement per unit sold that the intermediary enjoys when he raises his price is dominated by a business-loss effect. Moreover, at the level of the intermediary, there is no benefit that would correspond to the allocative effects for the downstream consumers.

From an economic perspective, the notion that damage awards should induce offenders to internalize all the external effects that they induce would warrant indirect as well as direct purchasers having the right to claim damages from the cartel. How this consideration would fit into the legal framework that is provided by general tort law is not a question that concerns the passing-on defense, but, rather, a question of what notion of causation one is relying on and what hypothetical alternative situation serves as a standard of comparison in assessing damages.

Along the lines of the argument in Section 2, providing the indirect purchaser with standing to claim damages against the cartel members would correspond to the notion that, without the cartel agreement, the indirect purchaser would have an option to buy whatever quantity he wants at the price $\mathrm{q}\left(\mathrm{p}^{\mathrm{C}}\right)$, which the intermediary would charge if the price of the input upstream was $\mathrm{p}^{\mathrm{C}}$. 
At a conceptual level, this raises the question to what extent the intermediary's response to the price-fixing upstream should be ascribed to the cartel members. At a practical level, it raises the question of how $\mathrm{q}\left(\mathrm{p}^{\mathrm{C}}\right)$ is to be ascertained. After all, this price is chosen by the intermediary and depends on the parameters of his profit function, rather than anything in the domain of the cartel members (except for the price that they charge). I will return to these questions below, after I have studied the case where the direct purchasers from the cartel are in competition with each other. This case raises similar questions, and it seems best to discuss these questions together.

At this point, it suffices to note that neither of these questions has anything to do with how the passing-on defense against direct buyers is treated. If the direct buyer is awarded damages according to both the allocative and the distributive effects of the price-fixing the passing-on defense is implicitly respected, and there is no reason to deny passing-on arguments brought by an indirect buyer. If the direct buyer is awarded less, in particular, if he is awarded only the actual overcharge, the same conclusion holds a fortiori. The United States Supreme Court reasoned to the contrary because it neglected the business-loss effect that resulted from the direct buyer's own price increase in response to price-fixing upstream. This neglect in turn was due to the insufficient attention paid to the allocative effects of the price-fixing upstream.

\section{The Effects of Price-fixing When Direct Buyers Are Competing With Each Other}

\subsection{Economic Analysis}

To conclude the economic analysis of private damages from price-fixing, I consider the case where intermediaries are in competition with each other in their downstream markets. I will not actually specify any details of the strategic interdependence which this creates. I merely consider a reduced form in which the downstream demand that is faced by any intermediary $i$ depends not just on this intermediary's own price $\mathrm{q}_{\mathrm{i}}$, but also on the prices that are charged by the other intermediaries. For simplicity, I assume that this influence is captured by some index $\mathrm{Q}$ of the other intermediaries' prices. ${ }^{16}$ The demand that intermediary $\mathrm{i}$ faces thus takes the form $\mathrm{E}_{\mathrm{i}}\left(\mathrm{q}_{\mathrm{i}}\right.$, $\mathrm{Q})$, rather than just $\mathrm{E}_{\mathrm{i}}\left(\mathrm{q}_{\mathrm{i}}\right)$. An increase in the competing firms' prices is assumed to make the intermediary's own offering more attractive to consumers so that $\mathrm{E}_{\mathrm{i}}\left(\mathrm{q}_{\mathrm{i}}, \mathrm{Q}\right)$ is increasing in $\mathrm{Q}$, as well as decreasing in $\mathrm{q}_{\mathrm{i}}{ }^{17}$

I again consider the effects of the cartelization upstream on the profits of one particular intermediary. To simplify the notation, I drop the subscript $\mathrm{i}$ for this intermediary unless there is a need for an explicit distinction between intermediaries. Thus, I write $\mathrm{E}(\mathrm{q}, \mathrm{Q})$ instead of $\mathrm{E}_{\mathrm{i}}\left(\mathrm{q}_{\mathrm{i}}, \mathrm{Q}\right)$, without thereby presuming that demand functions or prices are all the same.

I continue to assume that there are two inputs, one that is purchased from the cartel members and one that is not cartelized. The latter should again be interpreted as an aggregate of all other inputs; its price is again set equal to one. If the intermediary charges his own customers the price $\mathrm{q}$

\footnotetext{
16 Depending on the nature of the competition, Q might be an average, or Q might be the minimum, of the prices charged by the other intermediaries.

17 If $\operatorname{Ei}(.,$.$) is a continuous function, the underlying model of consumer preferences is one where the inter-$ mediaries' outputs are treated as imperfect substitutes, i.e., differentiated products. The case of perfect substitutes, i.e., homogeneous products, can be obtained as a limiting case of this specification.
} 
and if he purchases $\mathrm{x}$ units of the first input and $\mathrm{y}$ units of the second, he obtains the overall profit

$$
\mathrm{R}(\mathrm{q}, \mathrm{Q})-\mathrm{px}-\mathrm{y}
$$

where $\mathrm{R}(\mathrm{q}, \mathrm{Q})=\mathrm{q} \mathrm{E}(\mathrm{q}, \mathrm{Q})$ is the revenue obtained from selling $\mathrm{E}(\mathrm{q}, \mathrm{Q})$ units of output at the price q. Apart from the intermediary's own choices, this profit depends on the index $\mathrm{Q}$ of the prices set by his competitors, as well as the price $p$ at which he can buy the first input.

For given values of $\mathrm{p}$ and $\mathrm{Q}$, the intermediary may again be assumed to choose his own price $\mathrm{q}$ and his inputs $\mathrm{x}$ and $\mathrm{y}$ so as to maximize his overall profit under the constraint that the input combination ( $\mathrm{x}, \mathrm{y})$ be sufficient for him to produce the amount $\mathrm{E}(\mathrm{q}, \mathrm{Q})$ that he needs to satisfy his customers' demand. I denote his choices as $q(p, Q), d(p, Q)$, and $y(p, Q)$. These choices provide him with the maximal profit

$$
\mathrm{V}(\mathrm{p}, \mathrm{Q})=\mathrm{R}(\mathrm{q}(\mathrm{p}, \mathrm{Q}), \mathrm{Q})-\mathrm{p} \mathrm{d}(\mathrm{p}, \mathrm{Q})-\mathrm{y}(\mathrm{p}, \mathrm{Q}) .
$$

If $\mathrm{Q}$ could be taken as given, the analysis of the preceding section would be applicable without change. When cartel raises the intermediary's input price from $\mathrm{p}^{\mathrm{C}}$ to $\mathrm{p}^{\mathrm{M}}$, his maximal profit is lowered from $\mathrm{V}\left(\mathrm{p}^{\mathrm{C}}, \mathrm{Q}\right)$ to $\mathrm{V}\left(\mathrm{p}^{\mathrm{M}}, \mathrm{Q}\right)$. In a price-quantity diagram for the cartel good, the size of the loss would again be measured by the area of a trapezoid, this time between the vertical axis, the two horizontal lines at the prices $\mathrm{p}^{\mathrm{C}}$ and $\mathrm{p}^{\mathrm{M}}$, and the demand curve $\mathrm{d}(., \mathrm{Q})$ that corresponds to the given index $\mathrm{Q}$.

However, the index of prices that are charged by the other intermediaries cannot be taken as given! If the upstream producers all raise their price from $\mathrm{p}^{\mathrm{C}}$ to $\mathrm{p}^{\mathrm{M}}$, this also affects all the other intermediaries that use the cartel members' product as an input into their own production. Presumably, therefore, these intermediaries also want to raise their output prices. As they do so, the value of the index $Q$ goes up. This raises the demand for the intermediary's output at any price $\mathrm{q}$ that he might charge, i.e., the demand curve $\mathrm{E}(., \mathrm{Q})$ that he faces is shifted to the right (see Figure 5). This outward shift is likely to affect the intermediary's price and input choices. In particular, he may need more inputs to satisfy his customers' demand than he would if $Q$ remained unchanged.

In trying to assess how large these effects might be, one must come to terms with the strategic interdependence of the different intermediary firms. On the one hand, the output price $q$ that the given intermediary finds optimal depends on the index Q of the other intermediaries' prices, as well as the input price $p$. On the other hand, each of the other intermediaries is engaged in a similar calculation, with an index of prices charged by their competitors, into which the output price $\mathrm{q}$ of the first intermediary enters directly. 


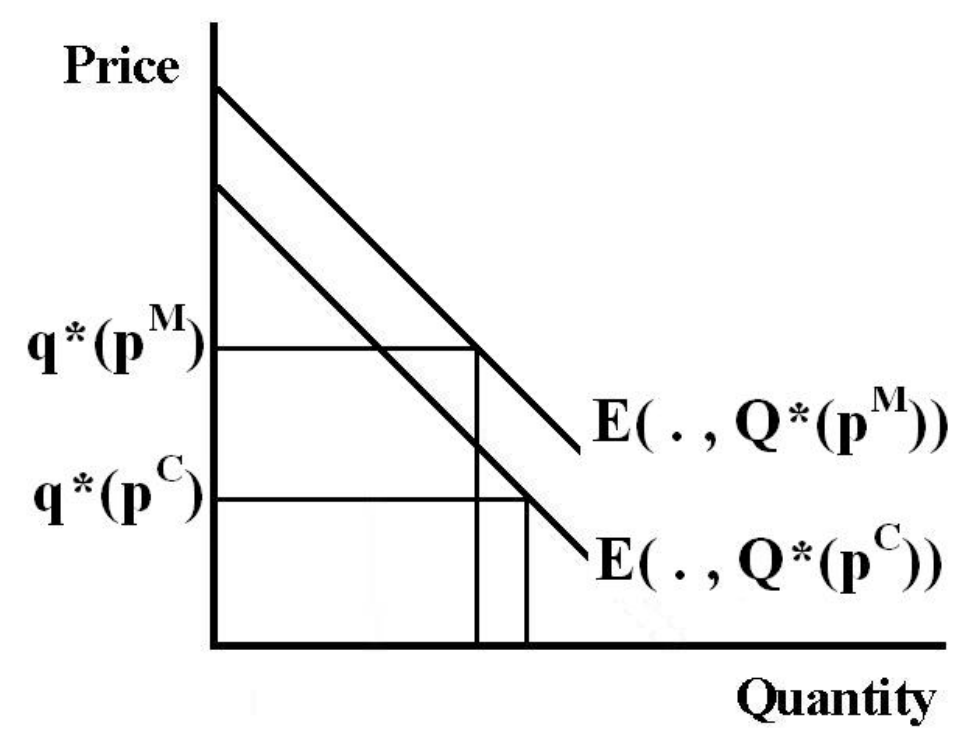

\section{Figure 5: The Effects of Upstream Price-fixing on Downstream Demand for a Direct Buyer When Direct Buyers Are in Competition With Each Other}

In this setting, each participant's behaviour depends on his expectations of all the other participants' behaviours. For any value $\mathrm{p}$ of the input price, an equilibrium induced by $\mathrm{p}$ is given by a list of price and input choices, one for each intermediary, such that, given the other intermediaries' choices, each intermediary is happy with the choices that the list stipulates for him. For a given intermediary, the triple $q^{*}(p), d^{*}(p), y^{*}(p)$ that is stipulated for him must correspond to the choices $q\left(p, Q^{*}(p)\right), d\left(p, Q^{*}(p)\right), y\left(p, Q^{*}(p)\right)$ that maximize his profit when the input price is $p$ and when the index of prices charged by the other intermediaries takes the value $Q^{*}(p)$ that results from the strategy choices that are stipulated for the other intermediaries. Thus, one must have

$$
\mathrm{q}^{*}(\mathrm{p})=\mathrm{q}\left(\mathrm{p}, \mathrm{Q}^{*}(\mathrm{p})\right), \mathrm{d}^{*}(\mathrm{p})=\mathrm{d}\left(\mathrm{p}, \mathrm{Q}^{*}(\mathrm{p})\right) \text {, and } \mathrm{y}^{*}(\mathrm{p})=\mathrm{y}\left(\mathrm{p}, \mathrm{Q}^{*}(\mathrm{p})\right){ }^{18}
$$

If any input price $p$ induces exactly one equilibrium of the strategic interaction between intermediaries, ${ }^{19}$ there is no ambiguity in saying that the increase in the upstream price from $\mathrm{p}^{\mathrm{C}}$ to $\mathrm{p}^{\mathrm{M}}$ has the effect of shifting the equilibrium of the downstream industry so that the intermediary chooses $\mathrm{q}^{*}\left(\mathrm{p}^{\mathrm{M}}\right), \mathrm{d}^{*}\left(\mathrm{p}^{\mathrm{M}}\right)$, and $\mathrm{y}^{*}\left(\mathrm{p}^{\mathrm{M}}\right)$ rather than $\mathrm{q}^{*}\left(\mathrm{p}^{\mathrm{C}}\right), \mathrm{d}^{*}\left(\mathrm{p}^{\mathrm{C}}\right)$, and $\mathrm{y}^{*}\left(\mathrm{p}^{\mathrm{C}}\right)$ and the index of prices charged by the other intermediary firms is $Q^{*}\left(p^{M}\right)$ rather than $Q^{*}\left(p^{C}\right)$; the price-fixing upstream affects the intermediary's behaviour both directly and indirectly, as he adjusts to the change in the prices that his competitors charge as well as the increase in the input price.

18 In the special case where the downstream demand function $\mathrm{E}(.,$.$) takes the same form for every intermedi-$ ary firm, all intermediaries have the same profit functions. In this case, the equilibrium may be presumed to be symmetric in the sense that all intermediaries end up making the same choices $q^{*}(p), d^{*}(p), y^{*}(p)$. The equilibrium value of the index $Q$ may then be identified with the common price $q^{*}(p)$; one may set $Q^{*}(p)=$ $\mathrm{q}^{*}(\mathrm{p})$. The common value of $\mathrm{Q}^{*}(\mathrm{p})$ and $\mathrm{q}^{*}(\mathrm{p})$ must then be a solution to the equation $\mathrm{q}^{*}=\mathrm{q}\left(\mathrm{p}, \mathrm{q}^{*}\right)$. In this equation, $\mathrm{q}^{*}$ enters in two functions, as the price charged by the maximizing intermediary, and as the price that this intermediary expects to be charged by his competitors.

There is not, in general, any reason why this should be so. I will return to this issue below. 
Figure 6 illustrates the effects on the intermediary's demand for the cartelized input. In this figure, $\mathrm{d}^{*}()=.\mathrm{d}\left(., \mathrm{Q}^{*}().\right)$ is the intermediary's equilibrium demand curve. This curve takes account of the endogeneity of $\mathrm{Q}^{*}($.$) ; \mathrm{d}\left(., \mathrm{Q}^{*}\left(\mathrm{p}^{\mathrm{C}}\right)\right)$ and $\mathrm{d}\left(., \mathrm{Q}^{*}\left(\mathrm{p}^{\mathrm{M}}\right)\right)$ are the intermediary's demand curve for fixed values $\mathrm{Q}^{*}\left(\mathrm{p}^{\mathrm{C}}\right)$ and $\mathrm{Q}^{*}\left(\mathrm{p}^{\mathrm{M}}\right)$ of the index of his competitor's prices. By definition, $d^{*}($.$) intersects d\left(., Q^{*}\left(p^{C}\right)\right)$ at the price $p^{C}$ and $d\left(., Q^{*}\left(p^{M}\right)\right)$ at the price $p^{M}$. The equilibrium demand curve $\mathrm{d}^{*}($.$) is steeper, i.e., less elastic, than the curves \mathrm{d}\left(., \mathrm{Q}^{*}\left(\mathrm{p}^{\mathrm{C}}\right)\right)$ and $\mathrm{d}($. , $\left.\mathrm{Q}^{*}\left(\mathrm{p}^{\mathrm{M}}\right)\right)$. The difference in elasticities reflects the fact that, when the upstream price goes up and the intermediary raises his own output price in response, at least some of the business-loss effect is compensated by a business-gain effect that is due to the other intermediaries raising their output prices as well.

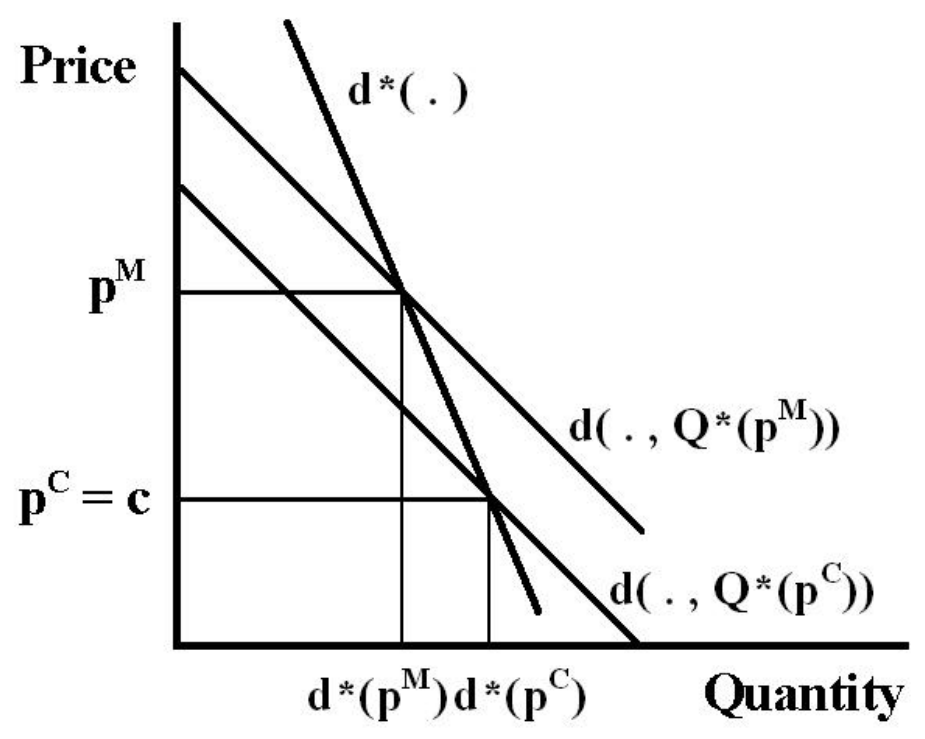

Figure 6: The Effects of Upstream Price-fixing on a Direct Buyer's Upstream Demand When Direct Buyers Are in Downstream Competition With Each Other

What can be said about welfare effects of the cartelization upstream? Any indirect buyer suffers from the fact that he faces higher prices from all intermediary firms. The resulting welfare decrease again consists of an allocative effect as he reduces his purchases and a distributive effect as he pays more for the purchases he still makes. The distributive effect of the cartelization upstream on the indirect buyer is given by the product $\left(\mathrm{q}^{*}\left(\mathrm{p}^{\mathrm{M}}\right)-\mathrm{q}^{*}\left(\mathrm{p}^{\mathrm{C}}\right)\right) \mathrm{e}\left(\mathrm{q}^{*}\left(\mathrm{p}^{\mathrm{M}}\right), \mathrm{Q}^{*}\left(\mathrm{p}^{\mathrm{M}}\right)\right)$ of the difference between the prices charged by the intermediary in the two situations with the quantity $\mathrm{e}\left(\mathrm{q}^{*}\left(\mathrm{p}^{\mathrm{M}}\right), \mathrm{Q}^{*}\left(\mathrm{p}^{\mathrm{M}}\right)\right)$ that the consumer purchases in the cartel situation. The allocative effect depends on the functioning of the competition among intermediaries and on the degree of product differentiation between the different intermediaries. Therefore, there is no simple and generally applicable way to compute this effect. In particular, as the index movement from $Q^{*}\left(p^{c}\right)$ to $\mathrm{Q}^{*}\left(\mathrm{p}^{\mathrm{M}}\right)$ shifts the indirect buyer's demand curve, there does not seem to be any way to relate the allocative effect to his demand behaviour in the market.

As for the intermediaries, they suffer from the fact that they face higher input prices, but they benefit from the fact that their competitors also face higher input prices. The latter effect enhances the distributive gains that they get from their own downstream customers. Indeed, this effect can be so strong that it outweighs the direct allocative and distributive effects of the input 
price increase. The intermediary's equilibrium profit $V\left(p^{M}, Q^{*}\left(p^{M}\right)\right)$ under price-fixing upstream is then actually larger than the equilibrium profit $\mathrm{V}\left(\mathrm{p}^{\mathrm{C}}, \mathrm{Q}^{*}\left(\mathrm{p}^{\mathrm{C}}\right)\right)$ that he gets if the upstream suppliers charge the competitive price $\mathrm{p}^{\mathrm{C}}$. The overall effect of the upstream cartelization on the intermediary can thus be a welfare gain, rather than a welfare loss.

To indicate why this can happen, I consider a particular example of the general structure considered here. In this example, there are many intermediaries, and all of them face a demand function of the same form. The demand $E_{i}\left(q_{i}, Q\right)$ that is faced by intermediary $i$ when he charges the price $\mathrm{q}_{\mathrm{i}}$ and when the index of prices charged by the other intermediaries takes the value $\mathrm{Q}$ is given as a product

$$
\mathrm{E}_{\mathrm{i}}\left(\mathrm{q}_{\mathrm{i}}, \mathrm{Q}\right)=\eta(\mathrm{Q}) \mathrm{f}\left(\mathrm{q}_{\mathrm{i}} / \mathrm{Q}\right)
$$

of a term $\eta(Q)$, which depends only on the index $Q$, and a term $f\left(q_{i} / Q\right)$, which depends only on the ratio of the intermediary's own price $\mathrm{q}_{i}$ to the index Q. I also assume that, when the input price is $\mathrm{p}$, all intermediaries produce at the same unit cost $\mathrm{k}(\mathrm{p})$, which, moreover, is independent of the quantity produced. Any one intermediary's profits thus take the form

$$
\left(q_{i}-k(p)\right) \eta(Q) f\left(q_{i} / Q\right) \text {. }
$$

The dependence of profits on $\mathrm{q}_{i}$ thus takes the same form for all intermediaries $i$, and, for any $p$ and $\mathrm{Q}$, the profit-maximizing prices $\mathrm{q}_{\mathrm{i}}$ may be taken to be the same for all $\mathrm{i}$. One may suppose that an equilibrium is symmetric, i.e., that, for any $p$, the intermediaries all choose the same price $\mathrm{q}_{\mathrm{i}}=\mathrm{q}^{*}(\mathrm{p})$, and the index $\mathrm{Q}$ takes the same value as the common price, i.e., $\mathrm{Q}^{*}(\mathrm{p})=\mathrm{q}^{*}(\mathrm{p})$. An example might be

$$
\mathrm{q}^{*}(\mathrm{p})=(1+\mathrm{m}) \mathrm{k}(\mathrm{p})
$$

which corresponds to a constant markup over unit cost. ${ }^{20}$ Equilibrium profits of an intermediary are equal to $\left(q^{*}(p)-k(p)\right)$ times his demand, i.e.,

$$
\left(q^{*}(p)-k(p)\right) \eta\left(Q^{*}(p)\right)=m k(p) \eta((1+m) k(p)) f(1) .
$$

It is quite possible for this expression to be increasing in $\mathrm{p}$. In fact, it must be increasing if the elasticity of the function $\eta($. ) is less than one, so that a $1 \%$ increase in $Q$ causes $\eta(Q)$ to decrease by less than $1 \%$. In this case, the intermediaries' equilibrium profits increase when the cartel price increase raises the their unit costs from $\mathrm{k}\left(\mathrm{p}^{\mathrm{C}}\right)$ to $\mathrm{k}\left(\mathrm{p}^{\mathrm{M}}\right)$.

The underlying logic is the following: In a symmetric equilibrium, with $\mathrm{q}^{*}(\mathrm{p})=\mathrm{Q}^{*}(\mathrm{p})$, the amount that any one intermediary sells depends mainly on the term $\eta\left(Q^{*}(p)\right)=\eta((1+m) k(p))$. By contrast, the term $\mathrm{f}\left(\mathrm{q}_{\mathrm{i}} / \mathrm{Q}\right)$ plays no role because the ratio $\mathrm{q}_{\mathrm{i}} / \mathrm{Q}$ is just equal to one. By contrast, at the level of individual profit maximization, behaviour is driven by the intermediaries' concerns about the term $\mathrm{f}\left(\mathrm{q}_{\mathrm{i}} / \mathrm{Q}\right)$, which captures the reaction of demand to a deviation of $\mathrm{q}_{\mathrm{i}}$ from the average $Q$. At this level, the term $\eta(Q)$ in the demand specification is irrelevant because the individual intermediary believes that he cannot affect it.

If the product $\mathrm{Q} \eta(\mathrm{Q})$ is an increasing function of $\mathrm{Q}$, the intermediaries all benefit from a joint increase in their prices. However, individually, they do not take this effect into account.

20 This constant markup rule actually corresponds to an equilibrium if the term $\mathrm{f}\left(\mathrm{q}_{\mathrm{i}} / \mathrm{Q}\right)$ in the demand specification takes the form $\left(\mathrm{Q} / \mathrm{q}_{\mathrm{i}}\right)^{1 /(1-\mathrm{a})}$ where $\mathrm{a}=1 /(1+\mathrm{m})$. This demand specification in turn is derived from consumers' utility maximization if utility depends on the amount e(i) purchsed from intermediary i only through the aggregate $\left[\int \mathrm{e}(\mathrm{i}) \mathrm{a} \mathrm{di}\right]^{1 / \mathrm{a}}$. 
The upstream cartel helps them to overcome this deficit. The increase in the intermediaries' unit $\operatorname{cost} \mathrm{k}(\mathrm{p})$ that is induced by the price-fixing upstream raises the price

$\mathrm{q}_{\mathrm{i}}=\mathrm{q}^{*}(\mathrm{p})$ that each intermediary charges as well as the index $\mathrm{Q}^{*}(\mathrm{p})=\mathrm{q}^{*}(\mathrm{p})$. If the elasticity of the function $\eta($.$) is less than one, this causes the product q^{*}(p) \eta\left(q^{*}(p)\right)$ to increase. To be sure, the cost $\mathrm{k}(\mathrm{p}) \eta\left(\mathrm{q}^{*}(\mathrm{p})\right)$ is also increasing, but, with an equilibrium output price determined by a constant markup over unit cost, the revenue increase exceeds the cost increase. As the profit $\mathrm{m}$ $\mathrm{k}(\mathrm{p}) \eta((1+\mathrm{m}) \mathrm{k}(\mathrm{p})) \mathrm{f}(1)$ is increasing in $\mathrm{k}(\mathrm{p})$, we may think of the upstream cartel as providing the intermediaries with a substitute for a cartel of their own.

This discussion should not be interpreted as saying that the intermediary firms necessarily gain from the price-fixing upstream. The example merely indicates that such a gain is possible. Indeed, for the very example given, the intermediary firms lose from the price-fixing upstream if the elasticity of the function $\eta($.$) is greater than one, so that the product k(p) \eta((1+m) k(p))$ decreases when $\mathrm{p}$ and $\mathrm{k}(\mathrm{p})$ are increased. However, even in this case, the intermediaries draw some benefit from the fact that the higher input price raises not only their own costs, but also the equilibrium prices of their competitors.

Unfortunately, there does not seem to be any way to relate the business-gain effect from the increase in $Q^{*}(p)$ to the participants' demand behaviour in the markets. In particular, the equilibrium demand curve $d^{*}($.$) , which reflects not only the direct effects of upstream prices, but also$ the indirect effects that occur through changes in the equilibrium index $\mathrm{Q}^{*}($. ), cannot be used to assess any welfare effects of the cartelization upstream.

\subsection{Legal Liabilities and the Assessment of Causation}

If we want legal damages to reflect the externalities that are caused by the price-fixing upstream, we should call for a regime that allows each affected party to claim economic private damages from the cartel members. In this case, the direct buyer could claim the difference $V\left(p^{C}, Q^{*}\left(p^{C}\right)\right)$ $\mathrm{V}\left(\mathrm{p}^{\mathrm{M}}, \mathrm{Q}^{*}\left(\mathrm{p}^{\mathrm{M}}\right)\right)$ between his equilibrium profits when the upstream price is $\mathrm{p}^{\mathrm{C}}$ and when it is $\mathrm{p}^{\mathrm{M}}$, and the indirect buyer could claim the sum of allocative and distributive effects that he suffers because the price increase upstream raises the prices that he has to pay the intermediaries.

However, such a regime would involve conceptual and procedural problems because the effects of the cartelization on the outcomes of competition between the direct buyers are difficult to handle. These effects shift part of the economic private damages from direct to indirect buyers. In dealing with the claims of indirect buyers, one must deal with the same questions as in the preceding section: To what extent is it appropriate to ascribe the intermediaries' responses to the price-fixing upstream to the cartel members? And: how is one to ascertain how the downstream prices to which the indirect buyer is exposed depend on the upstream prices of the cartel members? In the present setting, with competition among the intermediaries, these questions are even more difficult than before. Whereas before, an intermediary's reaction to the price-fixing upstream was a simple matter of optimization, in the present context, it is a matter of equilibrium interaction as all intermediaries jointly react to the price-fixing. If part of the increase in downstream prices is due to the effects of strategic interdependence among intermediaries, is it clear that the upstream suppliers could or should be held liable for this part of the downstream price increase? 
Economists think about causality in terms of the joint dependence of all the endogenous variables of a given system on all the exogenous variables. ${ }^{21}$ In the present instance, the cartel price, as an exogenous variable, affects all the intermediaries' downstream prices jointly. In a more complicated setting, one might also think of effects in additional markets. For instance, a cartel of oil producers might induce buyers to switch from oil to natural gas. This might raise the price of gas. Should we think of the welfare loss that is suffered by gas users as being the basis for claiming damages against the oil cartel? If so, how far along this line do we go? Are we not overtaxing the notion of legal responsibility if legal liability encompasses all the indirect effects, as well as the direct effects, including those indirect effects that arise from the "equilibrium reactions" of other people, i.e., fully responsible individual decision makers, to the initial violation?

In this context, one should also appreciate that, for a given constellation of exogenous variables, the system of endogenous variables may have more than one "equilibrium". ${ }^{22}$ In this case, we do not have any theory as to which of the different equilibria would be realized. There may, however, be circumstances where a change in exogenous variables induces the system to "jump" discontinuously from one equilibrium to another. In this case, the induced changes in endogenous variables will not be at all commensurate with the change in exogenous variables. An example is shown in Figure 7, where, for input prices in an intermediate range that includes $\mathrm{p}^{\mathrm{C}}$, the strategic interdependence of direct buyers generates three equilibria, rather than one, and the cartel's price-fixing induces a "jump" from the lower branch to the upper branch of the curve for Q* (. ..$^{23}$ Does it make sense to assign responsibility for such systemic reactions to the parties that are responsible for the illicit change in the input price?

21 For a general discussion of the economist's notion of causality, see Martin F. Hellwig, Zur Kategorie der Kausalität in den Wirtschaftswissenschaften, Max Planck Institute For Research on Collective Goods, Bonn, Preprint 10/2006, http://www.mpp-rdg.mpg.de/pdf_dat/2006_10online.pdf.

22 In the present context, a natural source of equilibrium multiplicity lies in the fact that the direct buyers' prices are what is known as strategic complements: If one intermediary raises his price, this makes it more attractive for others to raise their prices as well. On the concept of strategic complements, see Jeremy I. Bulow, John D. Geanakoplos, and Paul D. Klemperer, Multimarket Oligopoly: Strategic Substitutes and Complements, Journal of Political Economy 93 (1985), pp. 488 - 511; on strategic complementarity as a source of equilibrium multiplicity, see Russell Cooper and Andrew John, Coordinating Coordination Failures in Keynesian Models, Quarterly Journal of Economics 103 (1988), pp. 441 - 463.

23 As discussed in Hellwig (supra fn. 17), p. 10, such a jump may be unavoidable if the exogenous parameter crosses a boundary at which the number of equilibria changes, here from three to one. Lest the reader consider this to be a purely academic notion: The 1987 stock market crash has been interpreted as an instance of such an unavoidable jump, see Gerard Genotte and Hayne L. Leland, Market Liquidity, Hedging and Crashes, American Economic Review 80 (1990), 999-1021. 


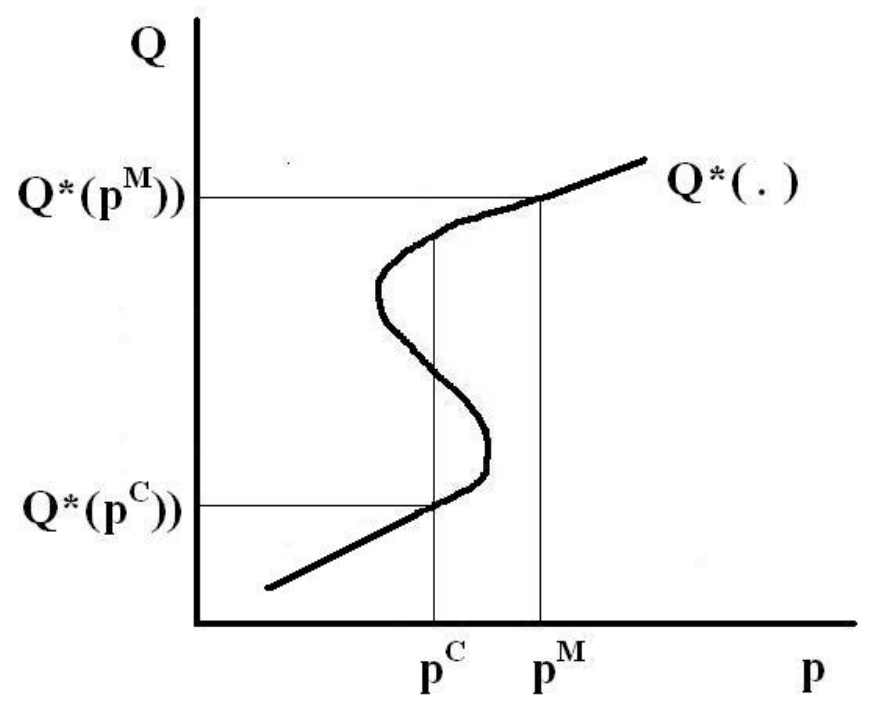

Figure 7: Systemic Reactions to Price-fixing When There Are Multiple Equilibria

Regardless of how we think about these questions at the conceptual level, we also have to appreciate that, at a practical level, the indirect buyers do not stand much of a chance to establish causality in legal proceedings. In practice, the price-fixing upstream is unlikely to be the only variable affecting the direct buyers' pricing policies downstream. How is the indirect buyer to show which part of the price increase that he suffered was due to the cartelization upstream and which part was due to other factors? Nota bene, he has to do so in a setting where the direct buyers' pricing policies downstream are determined jointly as an equilibrium response to the different factors affecting these firms' business considerations!

\subsection{An Alternative Approach to Assessing Causation and Liability}

If one rejects the notion that the cartel members upstream should be held legally responsible for all direct and indirect effects of their price-fixing on the overall equilibrium of the system, this should have consequences for the treatment of damage awards to the direct buyers. After all, the benefits that the direct buyer obtains from passing-on effects are entirely due to the effects of the upstream cartelization on the prices charged by his competitors. If one takes the position that indirect buyers should not be able to claim damages against the cartel members for the shift in the equilibrium among intermediaries, then as a matter of conceptual consistency one should also take the position that the shift in the equilibrium among intermediaries should not be used as a defense against damage claims by the direct buyers.

As before, the issue boils down to the question of what one takes to be the standard of comparison against which damages are being assessed. In the discussion so far, I have compared the overall equilibria of the system with and without price-fixing. An alternative approach would be to neglect equilibrium repercussions and to have each direct buyer claim damages on the basis that, if the cartel members had not conspired to fix the prices that they offer to him, then he 
would have had the option to buy any quantity at the competitive price $\mathrm{p}^{\mathrm{C}}$. Taking everything else as given, this would have provided him with the profit $\mathrm{V}\left(\mathrm{p}^{\mathrm{C}}, \mathrm{Q}^{*}\left(\mathrm{p}^{\mathrm{M}}\right)\right)$.

Under the latter construction of the hypothetical alternative situation, the direct buyer's welfare loss from the price-fixing upstream would be assessed as $\mathrm{V}\left(\mathrm{p}^{\mathrm{C}}, \mathrm{Q}^{*}\left(\mathrm{p}^{\mathrm{M}}\right)\right)$ -

$\mathrm{V}\left(\mathrm{p}^{\mathrm{M}}, \mathrm{Q}^{*}\left(\mathrm{p}^{\mathrm{M}}\right)\right)$. This quantity is always positive. By the same reasoning as in Section 3 , it is equal to the shaded area in Figure 8 below, i.e., the area of the trapezoid between the two horizontal lines at prices $\mathrm{p}^{\mathrm{C}}$ and $\mathrm{p}^{\mathrm{M}}$, the vertical axis, and the intermediary's demand curve

$\mathrm{d}\left(., \mathrm{Q}^{*}\left(\mathrm{p}^{\mathrm{M}}\right)\right)$ that takes the value $\mathrm{Q}^{*}\left(\mathrm{p}^{\mathrm{M}}\right)$ for the index of the other direct buyers' prices as given. This area is never less than the area of the trapezoid between the two horizontal lines at prices $\mathrm{p}^{\mathrm{C}}$ and $\mathrm{p}^{\mathrm{M}}$, the vertical axis, and the equilibrium demand curve $\mathrm{d}^{*}($.). The latter in turn is never less than the area of the rectangle with bases $d^{*}\left(p^{M}\right)=d\left(p^{M}, Q^{*}\left(p^{M}\right)\right)$ and height $p^{M}-p^{C}$, which represents the overcharge on the actual purchase $d^{*}\left(p^{M}\right)$.

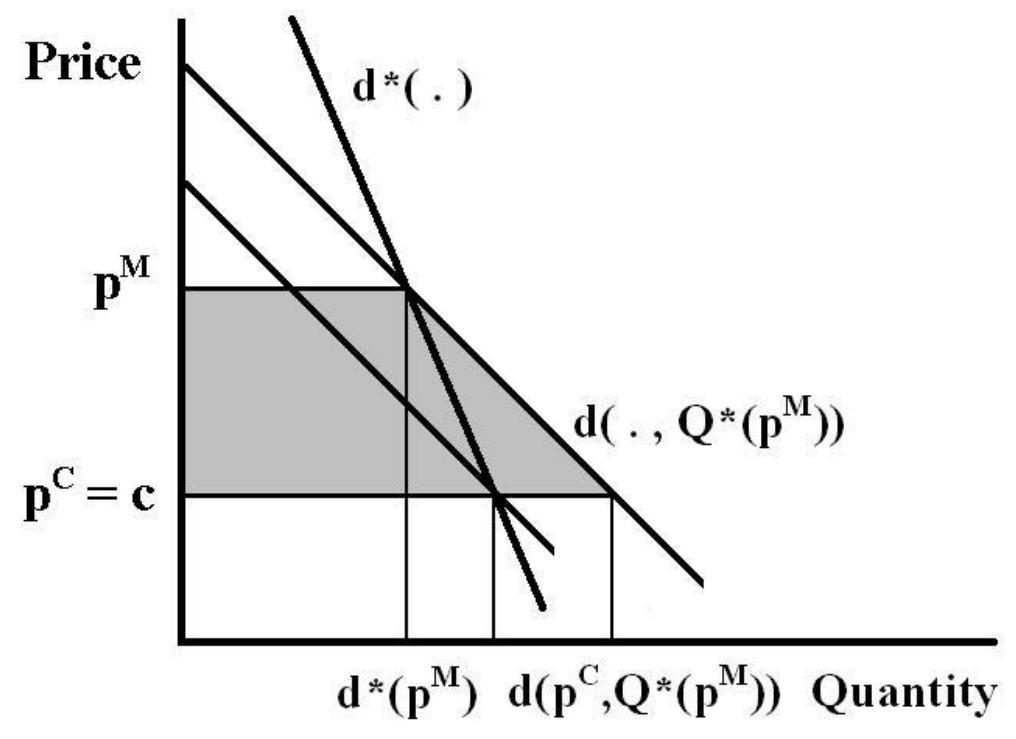

Figure 8: An Alternative Measure of Damages For the Direct Buyer

At this point, a lawyer for the defense may want to object that the difference $V\left(p^{C}, Q^{*}\left(p^{M}\right)\right)$ $\mathrm{V}\left(\mathrm{p}^{\mathrm{M}}, \mathrm{Q}^{*}\left(\mathrm{p}^{\mathrm{M}}\right)\right)$ exceeds the actual damage $\mathrm{V}\left(\mathrm{p}^{\mathrm{C}}, \mathrm{Q}^{*}\left(\mathrm{p}^{\mathrm{C}}\right)\right)-\mathrm{V}\left(\mathrm{p}^{\mathrm{M}}, \mathrm{Q}^{*}\left(\mathrm{p}^{\mathrm{M}}\right)\right)$ that the direct buyer actually suffers as a result of the price-fixing upstream. Awarding the direct buyer damages equal to $\mathrm{V}\left(\mathrm{p}^{\mathrm{C}}, \mathrm{Q}^{*}\left(\mathrm{p}^{\mathrm{M}}\right)\right)-\mathrm{V}\left(\mathrm{p}^{\mathrm{M}}, \mathrm{Q}^{*}\left(\mathrm{p}^{\mathrm{M}}\right)\right)$ would thus conflict with the principle of general tort law whereby damage payments should provide for equitable restitution and should not provide the tort victim with an opportunity for enrichment.

However, this objection presumes that the offensive acts for which the direct buyer claims damages comprise not only the fixed prices that the cartel members charged the direct buyer himself, but also the fixed prices that the cartel members charged the direct buyer's competitors; in addition, the competitors' reactions to this price-fixing must be treated as part of the offense. If, instead, the offensive acts for which the direct buyer claims damages comprise only the fixed prices that the cartel members charged this particular buyer, or if the other direct buyers' reactions to the price-fixing upstream are not ascribed to the cartel members, a ceteris paribus assumption concerning the index of prices charged by the direct buyer's competitors is in fact appropriate. The lawyer for the defense who calls for damages of the direct buyer to be awarded 
net of all passing-on effects is in fact asserting that the cartel members should be held responsible for the equilibrium reactions of the direct buyer's competitors. One may wonder whether the lawyer who presents this argument in a court case involving a direct buyer would as willingly adopt it in a case involving indirect buyers.

Two aspects of this discussion are important. First, the assessment of damages that for a direct buyer is again not so much a matter of principles concerning equitable restitution, as it is a matter of what precisely one construes to be the hypothetical alternative situation that provides the standard for damage assessment. If the offensive acts for which a direct buyer A claims damages are identified with the fixing of prices for this particular buyer, without any concern for what happens to the other direct buyers, B, C, D, etc., and what these buyers are doing, one is led to reject any argument that depends on the reactions of $\mathrm{B}, \mathrm{C}, \mathrm{D}$, etc. to the price-fixing upstream. In particular, one is led to reject any benefits that A obtains only because the demand function that he faces is shifted to the right when $\mathrm{B}, \mathrm{C}, \mathrm{D}$, etc. all raise their prices. Once this is done, one is effectively back in the conceptual framework of the preceding section, where competition among direct buyers played no role and passing-on effects were shown to be reinforcing, rather than detracting from, the distributive effect.

Second, it is desirable to have a certain consistency in the treatment of causation as a basis for assigning liability for damages. In particular, this treatment should be consistent across classes of claimants. If one asserts the principle that the effects of the price-fixing upstream on any participant are to be evaluated according to the overall change in the downstream equilibrium that is induced, then one should apply this principle to indirect and direct purchasers alike. If, alternatively, one takes the view that the indirect purchasers cannot hold the cartel members responsible for the change in the equilibrium of the strategic interaction between direct buyers, then one should also apply this principle to the direct purchasers, i.e., one should grant any direct purchaser the damages that are appropriate under the ceteris paribus assumption that the other direct purchasers prices remain the same.

This concern for consistency is reminiscent of the objections that the United States Supreme Court voiced in Illinois Brick against admitting a passing-on argument in a case involving an indirect purchaser while rejecting it in a case involving a direct purchaser. However, the issue at stake here is not the passing-on defense, but the business-gain effect that a direct purchaser enjoys when his competitors respond to the cartel members' price-fixing by raising their output prices. The passing-on defense has been shown to be irrelevant in that the per-unit revenue effect is outweighed by the business-loss effect of the intermediary's own price increase. The business-gain effect is what really matters. The treatment of this effect depends on the notion of causation on which one is relying. This notion of causation should be the same for different classes of claimants.

The concerns about incentives that the Supreme Court has voiced in Illinois Brick, as well as Hanover Shoe, would seem to suggest that the business-gain effect should be disregarded in cases involving direct, as well as indirect, purchasers. For direct purchasers, this would imply that damages are to be assessed according to the difference $\mathrm{V}\left(\mathrm{p}^{\mathrm{C}}, \mathrm{Q}^{*}\left(\mathrm{p}^{\mathrm{M}}\right)\right)-\mathrm{V}\left(\mathrm{p}^{\mathrm{M}}, \mathrm{Q}^{*}\left(\mathrm{p}^{\mathrm{M}}\right)\right)$, i.e., the shaded area in Figure 8. As mentioned above, a lower bound for this measure of damages is provided by the actual overcharge $\left(p^{M}-p^{C}\right) d^{*}\left(p^{M}\right)$. A somewhat tighter lower bound is provided by the trapezoid that lies to the left of the equilibrium demand function

$$
\mathrm{d}^{*}(.)
$$


What about indirect purchasers? The preceding discussion suggests that consistency in the treatments across classes of claimants is not a question of standing, but a question of what notion of causation one is working with. If the business-gain effect is disregarded for direct purchasers, then the indirect purchasers cannot hold the cartel members liable for the entire change in the equilibrium among intermediaries. As a practical matter, this eliminates most damage claims by indirect purchasers because they are hardly able to prove which parts of the high prices that they have to pay can be ascribed to the price-fixing upstream.

However, the assessment that indirect purchasers claims may be difficult to establish in practice is not a good reason for denying them standing. By giving the indirect purchasers standing to claim damages from the members of the upstream cartel, one can hope to counteract the incentives for implicit collusion between the upstream cartel and the direct purchasers. As mentioned above, if the business-gain effect from rivals' cost increases is sufficiently strong, the direct purchasers actually benefit from the cartelization upstream. ${ }^{24}$ Apart from follow-on suits, their incentives for suing cartel members for damages may therefore be weak even if damages are assessed without considering business-gain effects. In such a situation, allowing the indirect purchasers to sue for damages may provide a substitute threat against the upstream cartel. In some circumstances, the indirect purchasers may in fact be able to provide sufficient proof of a link between the high prices that they have to pay and the price-fixing upstream. In cases where the direct buyer follows a simple markup rule, e.g., when the direct buyer is a utility under a system of cost plus regulation, there should be no problem in doing so. ${ }^{25}$

\section{Concluding Remarks}

In its 2004 Special Report on the Reform of the Law Against Restraint of Competition, ${ }^{26}$ the German Monopolies Commission recommended that the passing-on defense be prohibited while allowing follow-on purchasers standing to claim damages against antitrust offenders. ${ }^{27}$ Because of the follow-on purchasers' difficulties in providing sufficient evidence for the damages that they suffer, the latter recommendation was held to be of practical significance only in those cases where the link between upstream and downstream prices was obvious and the direct purchasers might have few incentives to sue for damages themselves.

The recommendation to prohibit the passing-on defense was based on the same incentive considerations that motivated the United States Supreme Court in Hanover Shoe and Illinois Brick. The argument here has gone one step further and shown that the passing-on defense is actually irrelevant to a proper assessment of damages. Once one takes account of the allocative effect, as well as the distributive effect, of price-fixing, one sees that potential gains from passing-on effects are matched by the business loss that occurs because the increase in the downstream price lowers demand. I suspect that the irrelevance of the passing-on defense has gone unnoticed because allocative effects have been given insufficient attention and because passing-on effects have been mixed up with downstream-competition effects, i.e., the business-gain effect that a direct buyer enjoys when the cartelization upstream induces his competitors to raise their prices.

Schinkel et al. (supra fn. 5) show that this can be achieved quite generally, if the cartel members use more complicated pricing-and-rationing schemes for direct purchasers.

25 On this point, see Blair and Harrison (supra fn. 5).

26 Supra fn. 1.

27 This was of course the recommendation of Blair and Harrison (supra fn. 5). 
The effects of upstream cartelization on the outcomes of competition downstream are the most difficult issue in the assessment of damages for price-fixing. The analysis here proposes that this issue be handled analogously to the prevailing treatment of the passing-on defense, i.e., that, in awarding damages to a direct buyer from the cartel, the business-gain effect from price increases by the direct buyers' competitors be disregarded. By a suitable treatment of causation, such a procedure is easily reconciled with general principles of tort law, in particular, the principle that damage awards should not be a source of enrich the victim of the original offense.

The key to any assessment of damages in an antitrust case lies in the construction of the hypothetical alternative situation by comparison to which damages are to be assessed. Because pricefixing affects markets and markets are social systems, one has to come to terms with the fact that price-fixing may be changing the entire equilibrium of the system. Moreover, important parts of the change have to do with equilibrium interactions of different participants that cannot be reduced to simple sequences of causes and effects.

If private enforcement of antitrust law is to become effective, as well as reliable - for all parties concerned! - a major task will be to develop clear and general principles for the treatment of causation and for the construction of the hypothetical alternative situation by comparison to which damages are to be assessed. This paper has addressed some of the issues that this involves and indicated some of the alternatives that one might want to rely on. 


\section{Appendix}

In this Appendix, I establish the claim, made in Section 3.1, that, for a direct buyer who is a downstream monopolist, the welfare loss from price-fixing in his input market is measured by the shaded trapezoid in Figure 1, the area between the two horizontal lines at prices $\mathrm{p}^{\mathrm{C}}$ and $\mathrm{p}^{\mathrm{M}}$, the vertical axis, and the demand curve. For this purpose, I go back to the equation

$$
\mathrm{V}(\mathrm{p})=\mathrm{R}(\mathrm{q}(\mathrm{p}))-\mathrm{pd}(\mathrm{p})-\mathrm{y}(\mathrm{p})
$$

for the maximum profits of the intermediary as a function of the input price $p$. At the input price $\mathrm{p}$, the intermediary could also be making the choices $\mathrm{q}(\mathrm{p}+\Delta), \mathrm{d}(\mathrm{p}+\Delta), \mathrm{y}(\mathrm{p}+\Delta)$, which he makes when the input price is $p+\Delta$. The fact that, at the price $p$, he prefers the choices $q(p), d(p), y(p)$ means that

$$
\mathrm{V}(\mathrm{p}) \geq \mathrm{R}(\mathrm{q}(\mathrm{p}+\Delta))-\mathrm{pd}(\mathrm{p}+\Delta)-\mathrm{y}(\mathrm{p}+\Delta)
$$

Because

$$
V(p+\Delta)=R(q(p+\Delta))-(p+\Delta) d(p+\Delta)-y(p+\Delta)
$$

it follows that

$$
\mathrm{V}(\mathrm{p}) \geq \mathrm{V}(\mathrm{p}+\Delta)+\Delta \mathrm{d}(\mathrm{p}+\Delta)
$$

For any $\mathrm{p}$ and $\Delta$, the intermediary's welfare loss from a price increase from $\mathrm{p}$ to $\mathrm{p}+\Delta$ is bounded below by $\Delta \mathrm{d}(\mathrm{p}+\Delta)$, and one has

$$
V(p)-V(p+\Delta) \geq \Delta d(p+\Delta)
$$

Similarly, at the input price $\mathrm{p}+\Delta$, the intermediary considers the choices $\mathrm{q}(\mathrm{p}+\Delta), \mathrm{d}(\mathrm{p}+\Delta), \mathrm{y}(\mathrm{p}+\Delta)$, which he is taking at this price, to be at least as good as the choices $q(p), d(p), y(p)$ that he would take if the input price were $p$. Therefore,

$$
\mathrm{V}(\mathrm{p}+\Delta) \geq \mathrm{R}(\mathrm{q}(\mathrm{p}))-\mathrm{pd}(\mathrm{p})-\mathrm{y}(\mathrm{p}),
$$

and, by the same reasoning as before, one finds that

$$
\mathrm{V}(\mathrm{p})-\mathrm{V}(\mathrm{p}+\Delta) \leq \Delta \mathrm{d}(\mathrm{p}) .
$$

The difference $V(p)-V(p+\Delta)$, i.e., the intermediary's welfare loss from a price increase from $p$ to $\mathrm{p}+\Delta$, has thus been pinned down somewhere between $\Delta \mathrm{d}(\mathrm{p}+\Delta)$ and $\Delta \mathrm{d}(\mathrm{p})$. If we think of $\Delta$ as being small, so that $d(p)$ and $d(p+\Delta)$ are close to each other, the difference between the bounds $\Delta \mathrm{d}(\mathrm{p}+\Delta)$ and $\Delta \mathrm{d}(\mathrm{p})$ is small even in relation to $\Delta$. In a first approximation then, the welfare loss $\mathrm{V}(\mathrm{p})-\mathrm{V}(\mathrm{p}+\Delta)$ is approximately equal to the product of the increase $\Delta$ in the input price that he has to pay with his input demand $d(p)$.

Now think about the movement from $\mathrm{p}^{\mathrm{C}}$ to $\mathrm{p}^{\mathrm{M}}$ as being made up of some number $\mathrm{n}$ of small price increases, from $p^{C}$ to $p^{C}+\Delta$, from $p^{C}+\Delta$ to $p^{C}+2 \Delta$, etc., where $\Delta=\left(p^{M}-p^{C}\right) / n$, and consider the total loss $\mathrm{V}\left(\mathrm{p}^{\mathrm{C}}\right)-\mathrm{V}\left(\mathrm{p}^{\mathrm{M}}\right)$ as the sum of the losses from all these small price increases, i.e. the sum of the differences $\mathrm{V}\left(\mathrm{p}^{\mathrm{C}}+(\mathrm{k}-1) \Delta\right)-\mathrm{V}\left(\mathrm{p}^{\mathrm{C}}+\mathrm{k} \Delta\right)$ as $\mathrm{k}$ ranges from one to $\mathrm{n}$. For each $\mathrm{k}$, we know that $\mathrm{V}\left(\mathrm{p}^{\mathrm{C}}+(\mathrm{k}-1) \Delta\right)-\mathrm{V}\left(\mathrm{p}^{\mathrm{C}}+\mathrm{k} \Delta\right)$ lies above $\Delta \mathrm{d}\left(\mathrm{p}^{\mathrm{C}}+\mathrm{k} \Delta\right)$ and below $\Delta \mathrm{d}\left(\mathrm{p}^{\mathrm{C}}+(\mathrm{k}-1) \Delta\right)$. Therefore, $\mathrm{V}\left(\mathrm{p}^{\mathrm{C}}\right)-\mathrm{V}\left(\mathrm{p}^{\mathrm{M}}\right)$, as the sum of $\mathrm{V}\left(\mathrm{p}^{\mathrm{C}}+(\mathrm{k}-1) \Delta\right)-\mathrm{V}\left(\mathrm{p}^{\mathrm{C}}+\mathrm{k} \Delta\right)$ over all $\mathrm{k}$, must lie between the sums

$$
\sum_{k=1}^{n} \Delta \mathrm{d}\left(\mathrm{p}^{\mathrm{C}}+\mathrm{k} \Delta\right) \text { and } \sum_{k=1}^{n} \Delta \mathrm{d}\left(\mathrm{p}^{\mathrm{C}}+(\mathrm{k}-1) \Delta\right) .
$$




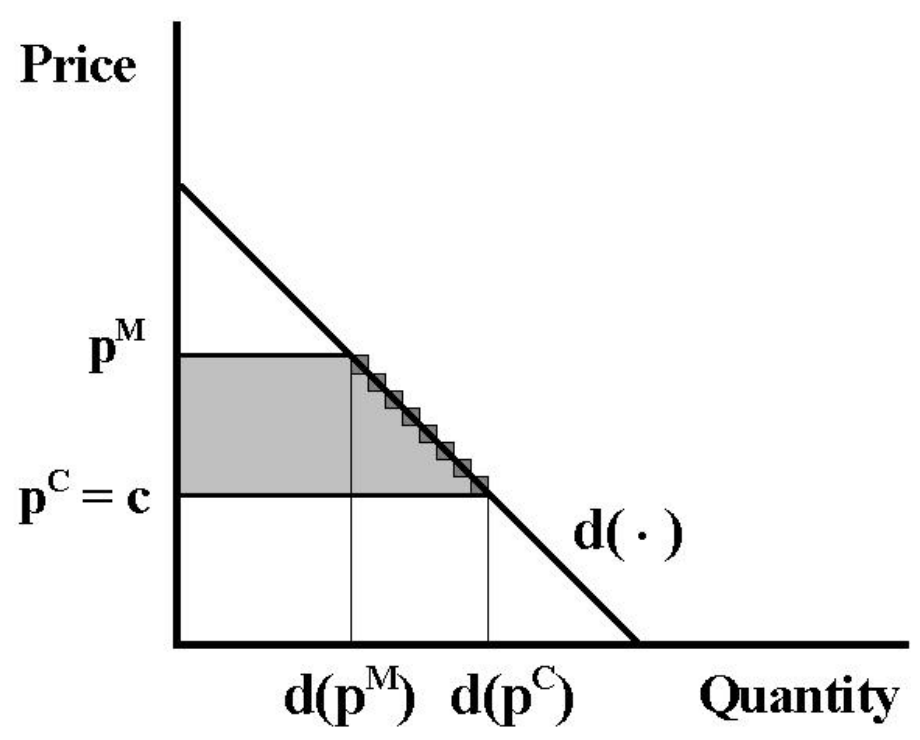

Figure 9: Lower and Upper Bounds on the Purchaser's Welfare Loss

For $n=8$, these bounds are illustrated by the two "staircases" in Figure 9. The lower bound is represented by the lightly shaded area between the two horizontal lines at prices $\mathrm{p}^{\mathrm{C}}$ and $\mathrm{p}^{\mathrm{M}}$, the vertical axis, and the "staircase" that lies below the demand curve. The upper bound is represented by the area between the two horizontal lines at prices $\mathrm{p}^{\mathrm{C}}$ and $\mathrm{p}^{\mathrm{M}}$, the vertical axis, and the "staircase" that lies above the demand curve; this corresponds to the sum of the lightly and darkly shaded areas in the figure. If I had chosen a larger number of "steps", e.g., $\mathrm{n}=16$, rather than $\mathrm{n}=8$, each individual step would only be half as large, and the darkly shaded area that represents the difference between the two bounds would be smaller. If one lets $n$ go out of bounds so that $\Delta=\left(p^{\mathrm{M}}-\mathrm{p}^{\mathrm{C}}\right) / \mathrm{n} \quad$ go to zero, the steps of the "staircases" become ever more numerous and ever smaller. Both bounds for the welfare loss then converge to the area of the trapezoid to the left of the demand curve. Because, for all $n$, the difference $V\left(p^{C}\right)-V\left(p^{M}\right)$ lies between these two bounds, one infers that $V\left(p^{C}\right)-V\left(p^{M}\right)$ is in fact equal to the area of the trapezoid. $^{28}$

28 The same reasoning can also be applied in the setting of Section 2, where the good is sold to a consumer. Suppose that the consumer's net payoff from buying an amount $\mathrm{x}$ of the good at the price $\mathrm{p}$ is equal to the difference $u(x)-p x$ between the utility he gets from consuming $x$ and the amount px that he pays for it. Thus, if he demands the quantity $d(p)$ at the price $p$, he gets the payoff $V(p)=u(d(p))-p d(p)$. If $d(p)$ maximizes $\mathrm{u}(\mathrm{x})-\mathrm{px}$ over $\mathrm{x}$, one has $\mathrm{V}(\mathrm{p}) \geq \mathrm{u}(\mathrm{d}(\mathrm{p}+\Delta))-\mathrm{pd}(\mathrm{p}+\Delta)=\mathrm{V}(\mathrm{p}+\Delta)+\Delta \mathrm{d}(\mathrm{p}+\Delta)$, and, similarly, $\mathrm{V}(\mathrm{p}+\Delta) \geq \mathrm{V}(\mathrm{p})-\Delta \mathrm{d}(\mathrm{p})$. The same reasoning as in the text then shows that the difference between $\mathrm{V}(\mathrm{p})$ and $\mathrm{V}(\mathrm{p}+\Delta)$ is equal to the shaded area in Figure 1, i.e., the trapezoid between the two horizontal lines at prices $\mathrm{p}^{\mathrm{C}}$ and $\mathrm{p}^{\mathrm{M}}$, the vertical axis, and the demand curve. 